\title{
The impacts of Elaeagnus umbellata Thunb. leaf and fruit aqueous extracts on mice hepatic, extrahepatic antioxidant and drug metabolizing enzymes related structures
}

\author{
Tevfik Ozen*, Kemal Yildirim, Mehmet Toka \\ Department of Chemistry, Faculty of Arts and Sciences, Ondokuz Mayis University, 55139-Samsun, Turkey
}

\begin{abstract}
In this work, the potential chemopreventive activities of Elaeagnus umbellata fruit aqueous (EUFA) and leaf aqueous (EULA) extracts focusing on the modulatory influence of xenobiotic metabolizing enzymes (XMEs), antioxidant enzymes, glucose-6-phosphate dehydrogenase (G6PD), 6-phosphogluconate dehydrogenase (6PGD), lactate dehydrogenase (LDH) activity, lipid peroxidation (LP), sulfhydryl groups were investigated in the hepatic and extrahepatic organs of Swiss albino mice (50 and $100 \mathrm{mg} / \mathrm{kg}$ body wt given orally for 14 days) and compared with $\mathrm{BHA}(0.75 \%$ in diet $)$. The modulatory and chemopreventive properties of two different doses EUFA and EULA were observed for cytochrome P450, cytochrome $\underline{\mathrm{b}}_{5}$, sulfhydryl groups, NADPH-cytochrome P450 reductase, NADH-cytochrome $\underline{\mathrm{b}}_{5}$ reductase, 7-ethoxyresorufin-deethylase and N,N-dimethylaniline N-oxidase activities in the liver and compared with BHA as a standard. The activities of glutathione S-transferase (GST) and DT-diaphorase (DTD) showed a significant increase in the kidney, forestomach, heart and brain at both doses of EUFA and EULA. The results of EULA-treated groups were found a notable increase in LDH, G6PD, 6PGD, GST and DTD activities. Superoxide dismutase level in liver, kidney and heart exhibited a significant increase at both doses of EULA. Glutathione reductase activity was a remarkable level at high dose of EUFA in liver, kidney and EULA in kidney. Both doses of EUFA were effective in inducing glutathione peroxidase activitiy in heart. The levels of LP at low and high doses of EULA-treated and EUFA-treated were effective in liver and kidney, respectively. The present results demonstrate that significant effects in the level of XMEs and antioxidant enzymes of EUFA and EULA are remarkable for modulating roles and natural chemoprevention properties and therefore is considered for a valuable natural source.
\end{abstract}

Keywords: Elaeagnus umbellata Thunb. Chemopreventive properties. Xenobiotic metabolizing enzymes. Antioxidant enzymes. Lipid peroxidation. Glutathione. Lactate dehydrogenase. Glucose-6-phosphate dehydrogenase. 6-Phosphogluconate dehydrogenase.

\section{INTRODUCTION}

Phenolic compounds found in natural products of plants and fruits have become important research topics due to their many bioactive properties such as anticarcinogenic, antiallergic, antimicrobial, antiinflammatory and antioxidant. It is known that these natural compounds prevent chain reactions that can lead to many diseases resulting from the deterioration of tissue functions such as cancer, cardiovascular, immunological system and degenerative diseases by neutralizing short-

\footnotetext{
*Correspondence: T. Ozen. Department of Chemistry, Faculty of Arts and Sciences, Ondokuz Mayis University, 55139-Samsun, Turkey. Tel: +90 362312 1919; fax: +90 362457 6081. E-mail: tevfikoz@omu.edu.tr
}

lived oxidative damage after metabolism in the human body (Gulcin, 2012).

Elaeagnus umbellata Thunb. (Elaeagnaceae; EU) tree is the most cultivated medicinal plant in Pakistan, China, Japan, and Korea, Afghanistan, India, USA and Canada, especially for its fruits because of its high medicinal and nutritional value of its berries (Patel, 2015). Different Elaeagnus species, E. angustifolia var. angustifolia (İğde), E. angustifolia var. turcica Yild. (Avanos iğdesi) and E. rhamnoides (Ç1çırgan) widely grow and their fruits are consumed in Turkey (Guner et al., 2012). EU (Güz yemişi) was introduced in Turkey as an ornamental plant and food to grow under natural conditions in the 1990s (Patel, 2015). EU grows especially river banks and seaside cliff areas around the province of Samsun in Northeastern Turkey 
(Ozen et al., 2017). The leaf of EU was traditionally used as a tonic and decoction to treat bowel disorders in Japan and China (Ito, Miki, Yoshida, 1999) according to traditional resources. Ellagitannins and their derivatives in the leaf of EU have chemopreventive, clinically-valuable activity as well as biological and nutraceutical potential (Ismail et al., 2016). The previous work indicated that the fruits of EU were consumed as fruit juice and healthy condiments (Fordham et al., 2001). The fruits, seeds and flowers of EU were used in the treatment of coughs, colon cancer, cardiac ailments and pulmonary infections (Afrin et al., 2016). Lycopene is a naturally occurring carotenoid compound widely found in the fruits of EU. Lycopene has a protective effect against neurological disorders and diseases including diabetes, cancer, alzheimer's and Parkinson's disease (Kaur et al., 2011).

Using medicinal plants as a chemoprevention agent is a promising approach for controlling cancer diseases. There are substantial evidences for plants to indicate that chemopreventive agents exert their anticarcinogenic effects by modulation of XMEs (phase I and II) in the liver. Cytochrome P450 (cyt.P450), a family of phase I hemoproteins, represents major adaptive response against chemical challenge from the environment and catalyzes the activation of various procarcinogens to ultimate carcinogens. Phase II enzymes detoxify pro- and ultimate forms of chemical carcinogens. The various carcinogens are associated with oxidative stress caused by reactive oxygen species (ROS) and free radicals generated in the living cells (Neki, 2015). Recently, there has been an extensive focus of research towards the new natural products that are chemoprentive and antioxidant sources (George, Dellaire, Rupasinghe, 2017). It was reported that leaf and fruit extracts of EU had the activities of in vitro antioxidant, antiproliferative and enzyme inhibition (Ozen et al., 2017). Due to active components, traditional utilizations and activities, the EUFA and EULA are considered to be in vivo chemopreventive potential and antioxidant potential.

Here, for the first time, the potential health and promoting effects of EULA and EUFA was investigated for their modulatory effects of phase I and II enzymes [cytochrome P450 (cyt.P450), cytochrome $\underline{\mathrm{b}}_{5}\left(\mathrm{cyt} . \underline{\mathrm{b}}_{5}\right)$, NADPH-cytochrome $\mathrm{P} 450$ reductase (cyt.P450R), NADH-cytochrome $\underline{\mathrm{b}}_{5}$ reductase (cyt. $\left.\underline{\mathrm{b}}_{5} \mathrm{R}\right)$, aniline 4-hydroxylase (A4H), 7-ethoxyresorufin-deethylase (EROD), $N, N$-dimethylaniline $N$-oxidase (NNDNO), glutathione S-transferase (GST), DT-diaphorase (DTD)], antioxidant enzymes [superoxide dismutase (SOD), catalase (CAT), glutathione reductase (GR) and glutathione peroxidase (GP)], sulfhydryl groups [total sulfhydryl groups (T-SH), nonprotein sulfhydryl groups
(NP-SH) and protein-bound sulfhydryl groups (PB-SH) groups], lactate dehydrogenase (LDH), glucose-6phosphate dehydrogenase (G6PD), 6-phosphogluconate dehydrogenase (6PGD) and level of lipid peroxidation (LP). Thus, the main purpose of the present research was to determinate the impact levels of EULA and EUFA on drug metabolizing and antioxidant enzymes related structures on liver, lung, kidney, forestomach, heart and brain of mice (Swiss albino), and also compared with BHA as a standard.

\section{MATERIAL AND METHODS}

\section{Chemicals}

Folin Ciocalteu's reagent, bovine serum albumin (BSA), 1-chloro-2,4-dinitrobenzene (CDNB), potassium ferricyanide, butylated hydroxyanisole (BHA), 5,5'-dithiobis-2-nitrobenzoic acid (DTNB), GSH, GSSG, cyt. c (from horse heart), 2,6-dichlorophenol-indophenol (DCPIP), sodium pyruvate, thiobarbituric acid (TBA), cholic acid, glucose 6-phosphate, 6-phosphogluconate, $\mathrm{NADP}^{+}, \mathrm{NADPH}+\mathrm{H}^{+}$and $\mathrm{NADH}+\mathrm{H}^{+}$were obtained from Sigma Chemical Co. USA. Ultra high purity CO (99\%) was a product of HABAS (Istanbul-Turkey). All other chemicals were analytical grade and purchased from commercial suppliers.

\section{Plant materials}

The fresh fruits and leaves of EU were collected randomly from Dogu Park, Samsun-Turkey in November 2014 and they were identified and confirmed by Prof. Dr. Hamdi Guray Kutbay, Department of Biology, Faculty of Arts and Sciences, Ondokuz Mayis University, where a voucher specimen (OMUB 7383) was deposited.

The dried plant materials were placed in boiled water for aqueous extraction. The mixture was sonicated and filtered through Whatman filter paper (No.1). The EUFA and EULA extracts were lyophilized in a lyophilizer (Christ Alpha 1-2 Model; Martin-Christ, Osterode, Germany) at $-50{ }^{\circ} \mathrm{C}$. The aquous powder crude extracts were kept in sterile tubes at $-20^{\circ} \mathrm{C}$ until using.

\section{Treatment schedule for animals}

In vivo experiments were conducted with permission from the local ethic committee for animal experiments. Ethical approval was obtained from the Ondokuz Mayis University Animal Ethics Committee (OMUHAYDEK: B.30.2.ODM.0.20.09.00-050.04-33. 2014/18.May-2014), Samsun, Turkey. Forty-eight adult male mice aged 
10-12 weeks old (35-45 g) were obtained from Laboratory Animal Research Unit (OMUDEHAM) from Ondokuz Mayis University, Samsun-Turkey. Mice were housed singly in plastic cages at room temperature with 12-hour light and dark cycle. Animals were fed with commercial rat chow (Nukleon Bil-Yem, Ankara-Turkey) and tap water ad libitum. The animals were randomly divided into six groups, containing each of eight animals as follows: Group I (negative control) was given double-distilled water daily (p.o.) for 14 days and fed normal diet. Groups II and III were orally given 50 and $100 \mathrm{mg} / \mathrm{kg}$ b.w. of EUFA dissolved double distilled water $(0.05 \mathrm{ml})$, respectively, for 14 days (p.o.). Groups IV and V were orally given 50 and $100 \mathrm{mg} / \mathrm{kg}$ b.w. of EULA dissolved double distilled water $(0.05 \mathrm{ml})$, respectively, for days (p.o.). Group VI (positive control) was fed a diet containing $0.75 \%$ BHA, daily for 14 days.

\section{Preparation of subcellular fractions of hepatic and extrahepatic organs}

The animals were killed by cervical dislocation after an overnight fast, and perfused with $0.9 \% \mathrm{NaCl}\left(+4{ }^{\circ} \mathrm{C}\right)$, and cleaned of blood due to diurnal variation, immediately. The liver, lung, kidney, forestomach, brain and heart were rinsed in ice-cold 0.15 M Tris-KCl buffer ( $\mathrm{pH} 7.4)$ and dried with filter paper. The organs were homogenized with ice-cold $0.15 \mathrm{M}$ Tris- $\mathrm{KCl}$ to yield $10 \%(\mathrm{w} / \mathrm{v})$ homogenate in an all-glass homogenizer. A $0.25 \mathrm{~mL}$ of liver homogenate was kept a refrigerator at $-80^{\circ} \mathrm{C}$ for determination of T-SH, NP-SH and PB-SH groups. The liver homogenate was centrifuged at $10.000 \mathrm{x} g$ in a Beckman Coulture Optimal L100XP ultracentrifuge (Beckman Model; California, USA) for $25 \mathrm{~min}$ at $+4{ }^{\circ} \mathrm{C}$. The supernatant was centrifuged at $105.000 \times \mathrm{g} 60 \mathrm{~min}+4{ }^{\circ} \mathrm{C}$ and separated cytosolic and microsomal fractions. After removing any floating lipid layer, the cytosol fractions were used for the assays of antioxidant enzymes, G6PD, 6PGD, GST, DTD, LDH activities and level of LP. The microsome fraction (enriched in endoplasmic reticulum) was prepared microsomal keeping buffer and transferred in pre-cooled sterile tubes. The fraction was used for assaying of cyt.P450, cyt. $\underline{b}_{5}$, cyt.P450R, cyt. $\underline{b}_{5} \mathrm{R}, \mathrm{A} 4 \mathrm{H}, \mathrm{EROD}, \mathrm{NNDNO}$ activities and level of LP. The lung, kidney, forestomach, brain and heart were homogenated in ice-cold $0.15 \mathrm{M}$ Tris- $\mathrm{KCl}$ buffer ( $\mathrm{pH}$ 7.4). The cytosolic fraction, after discarding lipid layer and appropriate dilution in pre-cooled centrifuge tubes, was obtained by centrifugation of $15.000 \mathrm{xg}$ for $25 \mathrm{~min}$ at $+4{ }^{\circ} \mathrm{C}$ and used for assaying of antioxidant enzymes, GST, DTD and level of LP. The cytosolic and microsomal fractions were kept a refrigerator at $-80{ }^{\circ} \mathrm{C}$ for further analysis.

\section{BIOCHEMICAL ASSAYS}

\section{Protein content}

The protein contents in the microsomal and cytosolic fractions were determined with BSA as standard at $660 \mathrm{~nm}$ (Lowry et al., 1951).

\section{Superoxide dismutase (SOD) activity}

The determination of SOD activity was based on measuring its ability to cyt.c reduction (Flohe, 1984). One unit of activity represents the amount inhibiting the cyt.c by $50 \%$. The activity of the SOD was calculated as U/mg cytosolic protein.

\section{Catalase (CAT) activity}

The activity was determined by following its ability to degrade using $\mathrm{H}_{2} \mathrm{O}_{2}$ as a substrate at $240 \mathrm{~nm}$ (Aebi, 1984). The CAT activity was calculated as a U/mg cytosolic protein.

\section{Glutathione peroxidase (GP) activity}

The GP activity was measured by the NADP ${ }^{+}$ consumption monitored at $340 \mathrm{~nm}$ according to ref (Ray et al., 2000). One unit of activity was calculated using an extinction coefficient of $6.22 \mathrm{mM}^{-1} \mathrm{~cm}^{-1}$ and expressed in terms of a nmole NADPH consumed/min/mg cytosolic protein.

\section{Glutathione reductase (GR) activity}

The activity was measured by with slight modification (Beutler, 1975) and defined as a nmole of $\mathrm{NADPH}$ consumed/min/mg cytosolic protein according to the molar extinction coefficient of $6.22 \mathrm{mM}^{-1} \mathrm{~cm}^{-1}$.

\section{Cytochrome P450 (cyt.P450) content}

The level of cyt.P450 content was quantified by using the $\mathrm{CO}$ difference spectra of sodium dithionite at $450-490 \mathrm{~nm}$, and defined as a nmol/min/mg microsomal protein using an extinction coefficient of $91 \mathrm{mM}^{-1} \mathrm{~cm}^{-1}$ (Omura, Sato, 1964a,b).

\section{Cytochrome $\underline{b}_{5}\left(\right.$ cyt. $\left.\underline{b}_{5}\right)$ content}

The level of cyt. $\underline{b}_{5}$ content was determined by following the difference of spectrum between reduced 
and oxidized cyt. $\underline{b}_{5}$ at 424-410 nm (Omura, Sato, 1964a). The cyt. $\underline{b}_{5}$ level was calculated relative to extinction coefficient of $185 \mathrm{mM}^{-1} \mathrm{~cm}^{-1}$ and expressed as a nmol/min/ $\mathrm{mg}$ microsomal protein.

\section{NADPH-cytochrome $\mathbf{P 4 5 0}$ reductase (cyt.P450R) activity}

The activity was determined by monitoring of the rate of reduction of cyt.c at 550-450 $\mathrm{nm}$ (Masters et al., 1967). The cyt.P450R activity was calculated using the extinction coefficient of $19.6 \mathrm{mM}^{-1} \mathrm{~cm}^{-1}$ and defined as a $\mu$ mole of NADH oxidized $/ \mathrm{min} / \mathrm{mg}$ microsomal protein.

\section{NADH-cytochrome $\underline{b}_{5}$ reductase $\left(\right.$ cyt. $\left.b_{5} \mathbf{R}\right)$ activity}

The activity was measured by the rate of reduction of $\mathrm{K}_{3} \mathrm{Fe}(\mathrm{CN})_{6}$, acted as an electron acceptor at 420 $\mathrm{nm}$ (Masters et al., 1967). The cyt. $\underline{b}_{5} \mathrm{R}$ activity was calculated using an extinction coefficient of $1.02 \mu \mathrm{M}^{-}$ ${ }^{1} \mathrm{~cm}^{-1}$ and defined as a $\mu$ mole of NADH oxidized $/ \mathrm{min} / \mathrm{mg}$ microsomal protein.

\section{Glutathione S-transferase (GST) activity}

The activity was performed by using CDNB as substrate at $340 \mathrm{~nm}$ (Simons, Vande Jagt, 1977). The GST activity was calculated using the extinction coefficient of $1.02 \mu \mathrm{M}^{-1} \mathrm{~cm}^{-1}$ and given as a $\mu$ mole CDNB-GSH conjugate formed $/ \mathrm{min} / \mathrm{mg}$ cytosolic protein.

\section{DT-diaphorase (DTD) activity}

The activity was based on NADPH as the electron donor and DCPIP acting as the electron acceptor/donors at $620 \mathrm{~nm}$ (Prochaska, 1988). The DTD activity was calculated using the extinction coefficient of $21 \mathrm{mM}^{-}$ ${ }^{1} \mathrm{~cm}^{-1}$ and expressed as a nmole DCPIP/min/mg cytosolic protein.

\section{Aniline 4-hydroxylase (A4H) activity}

The activity was determined by measuring the ratio of $p$-aminophenol formed by aniline as described in the reports (Ozen, Korkmaz, 2008; Emerole, Thabrew, 1983). The $\mathrm{A} 4 \mathrm{H}$ activity was defined as a nmole $p$-aminophenol formed/min/mg microsomal protein.

\section{7-Ethoxyresorufin-deethylase (EROD) activity}

The activity was determined by the procedure of
Klotz et al. (1984) at $572 \mathrm{~nm}$. The EROD activity was calculated using the extinction coefficient of $73 \mathrm{mM}^{-1} \mathrm{~cm}^{-1}$ and given as a nmole resorfin $/ \mathrm{min} / \mathrm{mg}$ microsomal protein.

\section{$\mathrm{N}, \mathrm{N}$-dimethylaniline $\mathrm{N}$-oxidase (NNDNO) activity}

The activity was determined in which N,Ndimethylaniline acted as a substrate at $420 \mathrm{~nm}$ (Schlenk, Buhler, 1991). The NNDNO activity was calculated using the extinction coefficient of $8.2 \mathrm{mM}^{-1} \mathrm{~cm}^{-1}$ and expressed as a nmole $\mathrm{N}, \mathrm{N}$-dimethylaniline oxidixed/min/ $\mathrm{mg}$ microsomal protein.

\section{Glucose-6-phosphate dehydrogenase (G6PD) activity}

The activity was determined in which glucose 6-phosphate acted as a substrate at $340 \mathrm{~nm}$ (Rudack, Davie, Holten, 1971) from the reduction of $\mathrm{NADP}^{+}$by taking the decrease of absorbance. The G6PD activity was calculated using the extinction coefficient of 6.22 $\mathrm{mM}^{-1} \mathrm{~cm}^{-1}$ and defined as a nmole NADPH reduced/min/ mg cytosolic protein.

\section{6-phosphogluconate dehydrogenase (6PGD) activity}

The activity was determined in which 6-phosphogluconate acted as a substrate at $340 \mathrm{~nm}$ (Rudack et al., 1971) from the reduction of $\mathrm{NADP}^{+}$by taking the decrease of absorbance. The 6PGD activity was calculated using the extinction coefficient of 6.22 $\mathrm{mM}^{-1} \mathrm{~cm}^{-1}$ and given as a nmole NADPH reduced $/ \mathrm{min} / \mathrm{mg}$ cytosolic protein.

\section{Determination of total sulfhydryl groups ( $T$ - $\mathrm{SH})$, nonprotein sulfhydryl groups (NP-SH) and protein-bound sulfhydryl groups (PB-SH) groups}

The levels of T-SH, NP-SH and PB-SH were estimated using DTNB (Sedlak, Lindsay, 1968) with slight modifications. The contents were defined as a $\mu$ mole of T-SH groups/g tissue, as a $\mu$ mole of NP-SH/g tissue and as a $\mu$ mole of PB-SH/g tissue, respectively.

\section{Lipid peroxidation (LP) assay}

The level of LP was determined as the level of nmole MDA formed $/ \mathrm{mg}$ protein at $532 \mathrm{~nm}$ in the microsomal and cytosolic fractions with respect to reference (Varshney, Kale, 1990). 


\section{Lactate dehydrogenase (LDH) activity}

The activity was determined the rate of oxidation of NADH at $340 \mathrm{~nm}$ (Narayan, Kumar, 2013). The LDH activity was calculated using extinction coefficient 6.22 $\mathrm{mM}^{-1} \mathrm{~cm}^{-1}$ and defined as a $\mu$ mole NAD ${ }^{+}$oxidized $/ \mathrm{min} /$ $\mathrm{mg}$ cytosolic protein.

\section{Statistics}

Results were expressed as mean \pm standard deviation (SEM). Statistical analysis was performed using the independent t-test, one-way ANOVA and MANOVA tests of with the multiple-comparison POST-HOC analysis (SPSS 20.0). The $p<0.05$ was considered to define the statistical comparison in assays.

\section{RESULTS AND DISCUSSION}

Phytochemicals studies are conducted to evaluate many pharmacological properties in herbal medicines. Effective investigations are performed to reveal potential natural resources for the prevention or treatment of diseases. The defensive systems of aerobic cells in the organism may be external (enzymatic and non-enzymatic) or nutrient derived (vitamins, caratinoids, flavonoids etc.) against reactive oxygen producing species for free radicals and prooxidants (Brisswalter, Louis, 2014). When natural defenses cannot remove the effect of prooxidants, both intracellular and extracellular macromolecules (proteins, lipids, and nucleic acids) are exposed to oxidative effects that cause cell damage. Epidemic studies support that abundant amounts of vegetables and fruits are associated with reduced risk of certain types of cardiovascular diseases and cancer (Wrafter et al., 2016). In recent years, natural bioactive secondary metabolits have been used as chemical protective reagents in cancer prevention in different forms. Pharmacological investigations involving chemical preservatives, which are natural products that delay the spread of cancer in normal or prenoplastic conditions have been increasing (Guarisco, Hall, Coulombe, 2008). Detoxification of xenobiotics is controlled by the liver, and also exists in the lung, kidney, forestomach, brain and heart.

In vivo application of two different doses of the EULA and EUFA extracts had a significant effect on the activity of certain hepatic XMEs and antioxidant enzymes. Extract applications of EU were able to regulate the activities of some XMEs and antioxidant enzyme systems which are important for moderator of enzymatic and nonenzymatic activation mechanisms.
In this investigation, BHA was used as a positive control in the experimental animal model system to support effective antioxidant activity and chemical protective efficacy (Ozen, Korkmaz, 2003; Guarisco, Hall, Coulombe, $2008)$. BHA (0.75\% in diet) and two different doses of EULA and EUFA ( 50 and $100 \mathrm{mg} / \mathrm{kg}$ body weight) were not observed a side effect in the experimental animals. Because the doses of BHA, EUFA and EULA which are free from all undesirable side effects, they did not have any significant toxic range and they are free from all undesirable side effects in the groups. Therefore, 14 day dosing was accepted for EUFA, EULA and BHA applications.

Oral administrations of 50 and $100 \mathrm{mg} / \mathrm{kg}$ EUFA and EULA extracts exhibited a significant decrease $(p<0.05)$ in body weight (b.w.) when compared to untreated control group. In Table I, the changes in body weights between day 0 and day 14 of the experimental animals of each group were calculated, and also the change rates were expressed as $\%$. There were significant changes in the level of relative weight of tissues (Table II).

No effects were observed on the destructive level of the BHA-treared group and regularly applied EULA and EUFA for experimental animals through the post-oral. The ratio of final b.w. to tissue weights of the experimental animals did not show a change in regulatory effect of normal body metabolism. LDH activity values at the cellular level indicate that EULA, EUFA(50 and $100 \mathrm{mg} / \mathrm{kg}$ body weight/14 days) and BHA (0.75\% in diet) had no effect on cell damage (Borges et al., 2008).

Table III represents the modulatory effects of cyt. P450 and cyt. $\underline{b}_{5}$ contents in the liver microsomes of the Swiss albino mice. There were significant increases in the cyt.P450 content by $49.62 \%, 51.56 \%, 87.87 \%$ and $40.10 \%$ in case of Group II, III, IV and V as compared with the corresponding animals of Group I (control), respectively. Cyt. $\underline{b}_{5}$ content was found an increase by $3.87 \%$ and $31.65 \%$ in treated-50 and $100 \mathrm{mg} / \mathrm{kg}$ b.w. of EUFA, respectively, as compared to the Group I (control). The activity of cyt. P450R extibited a significant enhancement $(p<0.05)$ in Group II and III (low and high dose of EUFA) by $1.59 \%$ and $21.20 \%$, respectively (Table IV). The cyt. $\underline{b}_{5}$ R activity was found a significant enhancement with Group II, III (low and high dose of EUFA) and IV (low dose of EULA) by $11.36 \%, 36.93 \%$ and $1.44 \%$, respectively $(p<0.05)$, as compared with respective control group (Table IV).

The activities of A4H, EROD and NNDNO in the liver microsomes were compared with their respective Group I (Table III). Group II, III, IV, V and VI animals in EROD and NNDNO activities were an increase as compared to the Group I. There was significantly increased A4H activities in the Group III in inspite of decreasing in 
TABLE I - Impact of EUFA, EULA and BHA on body weight in mice

\begin{tabular}{|c|c|c|c|c|}
\hline \multirow{2}{*}{ Group } & \multirow{2}{*}{ Treatment } & \multicolumn{2}{|c|}{ Body weight (b.w.), g } & \multirow{2}{*}{$\begin{array}{c}\text { Rate of Initial and Final } \\
\text { b.w. }\end{array}$} \\
\hline & & Initial & Final & \\
\hline $\mathrm{I}$ & $\begin{array}{c}\text { Control } \\
\text { (distilled water) }\end{array}$ & $45.63 \pm 1.77$ & $44.50 \pm 1.31$ & $2.47 \% \downarrow$ \\
\hline II & $\begin{array}{c}\text { EUFA } \\
\text { (50 } \mathrm{mg} / \mathrm{kg} \text { b.w.) }\end{array}$ & $42.00 \pm 3.63^{\mathrm{a}}$ & $39.00 \pm 2.62^{\mathrm{a}}$ & $7.14 \% \downarrow$ \\
\hline III & $\begin{array}{c}\text { EUFA } \\
(100 \mathrm{mg} / \mathrm{kg} \text { b.w. })\end{array}$ & $41.63 \pm 1.55^{\mathrm{b}}$ & $39.13 \pm 1.55^{\mathrm{b}}$ & $6.00 \% \downarrow$ \\
\hline IV & $\begin{array}{c}\text { EULA } \\
(50 \mathrm{mg} / \mathrm{kg} \text { b.w })\end{array}$ & $38.38 \pm 2.67^{\mathrm{c}}$ & $37.63 \pm 3.42^{\mathrm{c}}$ & $1.95 \% \downarrow$ \\
\hline $\mathrm{V}$ & $\begin{array}{c}\text { EULA } \\
(100 \mathrm{mg} / \mathrm{kg} \text { b.w. })\end{array}$ & $37.88 \pm 3.24^{\mathrm{d}}$ & $36.75 \pm 3.24^{\mathrm{d}}$ & $2.98 \% \downarrow$ \\
\hline VI & $\begin{array}{c}\text { BHA } \\
(0.75 \% \text { in diet })\end{array}$ & $40.88 \pm 1.36^{\mathrm{e}}$ & $40.88 \pm 1.81^{\mathrm{e}}$ & 0 \\
\hline
\end{tabular}

Data were expressed as mean \pm SEM of triplicate assays. Significant differences between dose groups and control were assayed by the use of ANOVA, $(p<0.05)$.

TABLE II - Impact of EUFA, EULA and BHA on relative weight of tissue

\begin{tabular}{|c|c|c|c|c|c|c|}
\hline \multirow{2}{*}{$\begin{array}{l}\text { Relative weight } \\
\text { of tissue (g): } \\
\text { Tissue weight/ } \\
\text { last b.w. x } 100\end{array}$} & \multirow[b]{2}{*}{ Control } & \multicolumn{5}{|c|}{ Treatment (fourteen days) } \\
\hline & & $\begin{array}{c}\text { EUFA } \\
(50 \mathrm{mg} / \mathrm{kg} \mathrm{b.w.)}\end{array}$ & $\begin{array}{c}\text { EUFA } \\
(100 \mathrm{mg} / \mathrm{kg} \mathrm{b.w.)}\end{array}$ & $\begin{array}{c}\text { EULA } \\
(50 \mathrm{mg} / \mathrm{kg} \mathrm{b.w.)}\end{array}$ & $\begin{array}{c}\text { EULA } \\
(100 \mathrm{mg} / \mathrm{kg} \mathrm{b.w.)}\end{array}$ & $\begin{array}{c}\text { BHA } \\
(0.75 \% \text { in diet })\end{array}$ \\
\hline Liver & $5.86 \pm 0.79^{\mathrm{a}}$ & $\begin{array}{l}5.88 \pm 0.95^{\mathrm{a}} \\
(0.34 \% \uparrow)^{*}\end{array}$ & $\begin{array}{l}5.74 \pm 0.70^{\mathrm{a}} \\
(2.00 \% \downarrow)^{*}\end{array}$ & $\begin{array}{l}5.01 \pm 0.42^{\mathrm{a}} \\
(14.51 \% \downarrow)^{*}\end{array}$ & $\begin{array}{l}4.84 \pm 0.43^{\mathrm{a}} \\
(17.44 \% \downarrow)^{*}\end{array}$ & $\begin{array}{c}6.68 \pm 0.49^{a} \\
(13.91 \% \uparrow)^{*}\end{array}$ \\
\hline Kidney & $1.79 \pm 0.18^{\mathrm{a}}$ & $\begin{array}{l}1.93 \pm 0.29^{\mathrm{ab}} \\
(7.82 \% \uparrow)^{*}\end{array}$ & $\begin{array}{l}1.91 \pm 0.14^{\mathrm{ab}} \\
(6.72 \% \uparrow)^{*}\end{array}$ & $\begin{array}{c}1.61 \pm 0.15^{\mathrm{b}} \\
(10.11 \% \downarrow)^{*}\end{array}$ & $\begin{array}{l}1.61 \pm 0.14^{\mathrm{b}} \\
(10.11 \% \downarrow)^{*}\end{array}$ & $\begin{array}{l}2.00 \pm 0.22^{\mathrm{b}} \\
(11.73 \% \uparrow)^{*}\end{array}$ \\
\hline Lung & $0.76 \pm 0.14^{\mathrm{a}}$ & $\begin{array}{l}0.92 \pm 0.26^{\mathrm{ab}} \\
(21.11 \% \uparrow)^{*}\end{array}$ & $\begin{array}{l}0.88 \pm 0.17^{\mathrm{ab}} \\
(15.76 \% \uparrow)^{*}\end{array}$ & $\begin{array}{l}0.96 \pm 0.14^{\mathrm{ab}} \\
(26.29 \% \uparrow)^{*}\end{array}$ & $\begin{array}{l}0.75 \pm 0.11^{\mathrm{ab}} \\
(1.28 \downarrow \%)^{*}\end{array}$ & $\begin{array}{c}0.97 \pm 0.11^{\mathrm{b}} \\
(27.63 \uparrow \%)^{*}\end{array}$ \\
\hline Forestomach & $0.25 \pm 0.04^{\mathrm{a}}$ & $\begin{array}{l}0.26 \pm 0.05^{\mathrm{a}} \\
(4.00 \% \uparrow)^{*}\end{array}$ & $\begin{array}{l}0.25 \pm 0.05^{\mathrm{a}} \\
(0.00 \%)^{*}\end{array}$ & $\begin{array}{l}0.22 \pm 0.04^{\mathrm{a}} \\
(12.00 \% \downarrow)^{*}\end{array}$ & $\begin{array}{l}0.23 \pm 0.06^{\mathrm{a}} \\
(8.00 \% \downarrow)^{*}\end{array}$ & $\begin{array}{l}0.22 \pm 0.10^{\mathrm{a}} \\
(12.13 \% \downarrow)^{*}\end{array}$ \\
\hline Heart & $0.50 \pm 0.06^{\mathrm{a}}$ & $\begin{array}{l}0.56 \pm 0.08^{\mathrm{ab}} \\
(12.12 \% \uparrow)^{*}\end{array}$ & $\begin{array}{c}0.50 \pm 0.04^{\mathrm{ab}} \\
(0.00)^{*}\end{array}$ & $\begin{array}{l}0.46 \pm 0.03^{\mathrm{ab}} \\
(8.00 \% \downarrow)^{*}\end{array}$ & $\begin{array}{l}0.49 \pm 0.07^{\mathrm{ab}} \\
(2.00 \% \downarrow)^{*}\end{array}$ & $\begin{array}{c}0.59 \pm 0.07^{\mathrm{b}} \\
(18.14 \% \uparrow)^{*}\end{array}$ \\
\hline Brain & $0.94 \pm 0.07^{\mathrm{a}}$ & $\begin{array}{l}1.06 \pm 0.07^{\mathrm{ab}} \\
(12.82 \% \uparrow)^{*}\end{array}$ & $\begin{array}{l}1.05 \pm 0.07^{\mathrm{ab}} \\
(11.74 \% \uparrow)^{*}\end{array}$ & $\begin{array}{c}1.14 \pm 0.1^{\mathrm{b}} \\
(21.33 \% \uparrow)^{*}\end{array}$ & $\begin{array}{l}1.22 \pm 0.07^{\mathrm{b}} \\
(29.46 \% \uparrow \uparrow)^{*}\end{array}$ & $\begin{array}{c}1.11 \pm 0.04^{\mathrm{b}} \\
(18.12 \% \uparrow)^{*}\end{array}$ \\
\hline
\end{tabular}

*Data were expressed as mean \pm SEM of triplicate assays and significant difference from control values. Significant differences between dose groups and control were assayed by the use of ANOVA, $(p<0.05)$.

the other groups. A4H activity exhibited a reduction effect in BHA group (Group III), whereas EROD and NNDNO increased $(p<0.05)$.

The microsomal cyt.P450 system, a product of the cytochrome superfamily family, is the main electron transport chain in the endoplasmic reticulum membrane. In the microsomes containing the cyt.P450 system, electrons flow to different isomorphic factors of NADPH or NADH from cyt.P450 and cyt. $\underline{\mathrm{b}}_{5}$ via flavoprotein cyt. $\underline{b}_{5} \mathrm{R}$ or cyt.P450R, respectively and have an effective role in the detoxification of many xenobiotic compounds. The primary function of phase I metabolism is the ease of drug absorption and its effect on compound preparation for phase II metabolism. Phase II metabolism is detrimental to xenobiotics and drug detoxification in obtaining water-soluble products (Kiruthiga et al., 2015). In vivo studies, cyt. $\underline{b}_{5}$ and cyt. $\underline{b}_{5} \mathrm{R}$ increased levels of all measured components. Thus, the effects of EULA and EUFA in cyt. $\underline{b}_{5}$ content may be effective in the metabolism of carcinogens. The levels of AH, EROD and also NNDNO 
The impacts of Elaeagnus umbellata Thunb. leaf and fruit aqueous extracts on mice hepatic, extrahepatic antioxidant and drug metabolizing enzymes

TABLE III - Impact of oral treatments with EUFA, EULA and BHA on phase I hepatic xenobiotic metabolizing enzymes in mice.

\begin{tabular}{|c|c|c|c|c|c|c|}
\hline \multirow{2}{*}{$\begin{array}{l}\text { XME } \\
\text { (phase I } \\
\text { enzymes) }\end{array}$} & \multirow[b]{2}{*}{ Control } & \multicolumn{5}{|c|}{ Treatment (fourteen days) } \\
\hline & & $\begin{array}{c}\text { EUFA } \\
(50 \mathrm{mg} / \mathrm{kg} \text { b.w. })\end{array}$ & $\begin{array}{c}\text { EUFA } \\
(100 \mathrm{mg} / \mathrm{kg} \mathrm{b.w.})\end{array}$ & $\begin{array}{c}\text { EULA } \\
(50 \mathrm{mg} / \mathrm{kg} \mathrm{b.w.)}\end{array}$ & $\begin{array}{c}\text { EULA } \\
(100 \mathrm{mg} / \mathrm{kg} \mathrm{b.w.})\end{array}$ & $\begin{array}{c}\text { BHA } \\
\text { (0.75\% in diet) }\end{array}$ \\
\hline $\begin{array}{l}\text { Cyt.P450 } \\
\text { (pmol/min/mg) }\end{array}$ & $0.99 \pm 0.26$ & $\begin{array}{c}1.48 \pm 0.44^{\mathrm{a}} \\
(49.62 \% \uparrow)^{*}\end{array}$ & $\begin{array}{c}1.50 \pm 0.53^{b} \\
(51.56 \% \uparrow)^{*}\end{array}$ & $\begin{array}{c}1.85 \pm 0.50^{\mathrm{c}} \\
(87.87 \% \uparrow)^{*}\end{array}$ & $\begin{array}{c}1.38 \pm 0.33^{\mathrm{d}} \\
(40.10 \% \uparrow)^{*}\end{array}$ & $\begin{array}{l}0.90 \pm 0.08^{\mathrm{e}} \\
(9.24 \% \downarrow)^{*}\end{array}$ \\
\hline $\begin{array}{l}\text { Cyt. } \underline{\mathbf{b}}_{5} \\
(\mathrm{pmol} / \mathrm{min} / \mathrm{mg})\end{array}$ & $1.24 \pm 0.16$ & $\begin{array}{l}1.29 \pm 0.23^{\mathrm{a}} \\
(3.87 \% \uparrow)^{*}\end{array}$ & $\begin{array}{c}1.64 \pm 0.54^{\mathrm{b}} \\
(31.65 \% \uparrow)^{*}\end{array}$ & $\begin{array}{c}0.96 \pm 0.42^{\mathrm{c}} \\
(23.02 \% \downarrow)^{*}\end{array}$ & $\begin{array}{c}0.76 \pm 0.24^{\mathrm{d}} \\
(39.24 \% \downarrow)^{*}\end{array}$ & $\begin{array}{c}0.76 \pm 0.15^{\mathrm{e}} \\
(38.59 \% \downarrow)^{*}\end{array}$ \\
\hline $\begin{array}{l}\text { Cyt.P450R } \\
\text { (pmoles/min/mg) }\end{array}$ & $0.56 \pm 0.06$ & $\begin{array}{l}0.57 \pm 0.11^{\mathrm{a}} \\
(1.59 \% \uparrow)^{*}\end{array}$ & $\begin{array}{c}0.68 \pm 0.04^{\mathrm{b}} \\
(21.20 \% \uparrow)^{*}\end{array}$ & $\begin{array}{l}0.56 \pm 0.13^{\mathrm{c}} \\
(0.32 \% \downarrow)^{*}\end{array}$ & $\begin{array}{c}0.37 \pm 0.05^{\mathrm{d}} \\
(34.01 \% \downarrow)^{*}\end{array}$ & $\begin{array}{c}0.44 \pm 0.07^{\mathrm{e}} \\
(21.23 \% \downarrow)^{*}\end{array}$ \\
\hline $\begin{array}{l}\text { Cyt. } \underline{b}_{5} \mathbf{R} \\
\text { (pmoles /min/mg) }\end{array}$ & $7.98 \pm 1.08$ & $\begin{array}{l}8.88 \pm 1.48^{\mathrm{a}} \\
(11.36 \% \uparrow)^{*}\end{array}$ & $\begin{array}{l}10.92 \pm 2.08^{b} \\
(36.93 \% \uparrow)^{*}\end{array}$ & $\begin{array}{l}8.09 \pm 1.42^{\mathrm{c}} \\
(1.44 \% \uparrow)^{*}\end{array}$ & $\begin{array}{c}3.94 \pm 1.24^{\mathrm{d}} \\
(50.57 \% \downarrow)^{*}\end{array}$ & $\begin{array}{c}6.56 \pm 1.31^{\mathrm{e}} \\
(17.83 \% \downarrow)^{*}\end{array}$ \\
\hline $\begin{array}{l}\mathbf{A 4 H} \\
(\mathrm{nmole} / \mathrm{min} / \mathrm{mg})\end{array}$ & $12.04 \pm 1.50$ & $\begin{array}{c}11.92 \pm 1.98^{\mathrm{a}} \\
(0.97 \% \downarrow)^{*}\end{array}$ & $\begin{array}{l}14.13 \pm 2.18^{\mathrm{b}} \\
(17.37 \% \uparrow)^{*}\end{array}$ & $\begin{array}{c}9.89 \pm 1.89^{\mathrm{c}} \\
(17.87 \% \downarrow)^{*}\end{array}$ & $\begin{array}{c}8.01 \pm 0.76^{\mathrm{d}} \\
(33.50 \% \downarrow)^{*}\end{array}$ & $\begin{array}{c}8.69 \pm 1.10^{\mathrm{e}} \\
(27.85 \% \downarrow)^{*}\end{array}$ \\
\hline $\begin{array}{l}\text { EROD } \\
\text { (pmolen/min/mg) }\end{array}$ & $0.292 \pm 0.05$ & $\begin{array}{l}0.362 \pm 0.08^{\mathrm{a}} \\
(23.84 \% \uparrow)^{*}\end{array}$ & $\begin{array}{l}0.42 \pm 0.12^{\mathrm{b}} \\
(43.01 \% \uparrow)^{*}\end{array}$ & $\begin{array}{c}0.35 \pm 0.10^{c} \\
(18.25 \% \uparrow)^{*}\end{array}$ & $\begin{array}{l}0.32 \pm 0.08^{\mathrm{d}} \\
(7.97 \% \uparrow)^{*}\end{array}$ & $\begin{array}{l}0.30 \pm 0.04^{e} \\
(1.73 \% \uparrow)^{*}\end{array}$ \\
\hline $\begin{array}{l}\text { NNDNO } \\
(\mathrm{pmole} / \mathrm{min} / \mathrm{mg})\end{array}$ & $0.30 \pm 0.05$ & $\begin{array}{c}0.36 \pm 0.08^{\mathrm{a}} \\
(23.84 \% \uparrow)^{*}\end{array}$ & $\begin{array}{c}0.42 \pm 0.12^{\mathrm{b}} \\
(43.01 \% \uparrow)^{*}\end{array}$ & $\begin{array}{c}0.35 \pm 0.10^{\mathrm{c}} \\
(18.25 \% \uparrow)^{*} \\
\end{array}$ & $\begin{array}{l}0.32 \pm 0.08^{\mathrm{d}} \\
(7.97 \% \uparrow)^{*}\end{array}$ & $\begin{array}{l}0.30 \pm 0.04^{e} \\
(1.73 \% \uparrow)^{*}\end{array}$ \\
\hline
\end{tabular}

*Data were expressed as mean \pm SEM of triplicate assays and significant difference from control values. Significant differences between dose groups and control were assayed by the use of ANOVA, $(p<0.05)$.

TABLE IV - Impact of EUFA, EULA and BHA on GST activity in mice

\begin{tabular}{|c|c|c|c|c|c|c|}
\hline \multirow{2}{*}{$\begin{array}{l}\text { XME (phase II) } \\
\text { GST (nmole/ } \\
\text { min/mg ) }\end{array}$} & \multirow[b]{2}{*}{ Control } & \multicolumn{5}{|c|}{ Treatment (fourteen days) } \\
\hline & & $\begin{array}{c}\text { EUFA } \\
\text { (50 } \mathrm{mg} / \mathrm{kg} \text { b.w.) } \\
\end{array}$ & $\begin{array}{c}\text { EUFA } \\
(100 \mathrm{mg} / \mathrm{kg} \text { b.w. })\end{array}$ & $\begin{array}{c}\text { EULA } \\
(50 \mathrm{mg} / \mathrm{kg} \text { b.w.) } \\
\end{array}$ & $\begin{array}{c}\text { EULA } \\
(100 \mathrm{mg} / \mathrm{kg} \text { b.w. }) \\
\end{array}$ & $\begin{array}{c}\text { BHA } \\
(0.75 \% \text { in diet }) \\
\end{array}$ \\
\hline Liver & $9.42 \pm 0.42$ & $\begin{array}{l}9.92 \pm 1.73^{\mathrm{a}} \\
(5.32 \% \uparrow)^{*}\end{array}$ & $\begin{array}{c}7.62 \pm 0.99^{\mathrm{b}} \\
(19.09 \% \downarrow)^{*}\end{array}$ & $\begin{array}{l}8.61 \pm 1.38^{\mathrm{c}} \\
(8.58 \% \downarrow)^{*}\end{array}$ & $\begin{array}{l}9.05 \pm 1.48^{\mathrm{d}} \\
(3.91 \% \downarrow)^{*}\end{array}$ & $\begin{array}{l}9.97 \pm 1.56^{\mathrm{e}} \\
(5.82 \% \uparrow)^{*}\end{array}$ \\
\hline Kidney & $5.88 \pm 0.78$ & $\begin{array}{l}6.01 \pm 0.90^{\mathrm{a}} \\
(2.23 \% \uparrow)^{*}\end{array}$ & $\begin{array}{c}7.10 \pm 0.54^{\mathrm{b}} \\
(20.76 \% \uparrow)^{*}\end{array}$ & $\begin{array}{c}6.82 \pm 1.07^{c} \\
(16.03 \% \uparrow)^{*}\end{array}$ & $\begin{array}{l}7.50 \pm 0.91^{\mathrm{d}} \\
(27.54 \% \uparrow)^{*}\end{array}$ & $\begin{array}{l}6.40 \pm 0.76^{\mathrm{e}} \\
(8.76 \% \uparrow)^{*}\end{array}$ \\
\hline Lung & $9.07 \pm 1.18$ & $\begin{array}{l}9.83 \pm 4.28^{\mathrm{a}} \\
(8.35 \% \uparrow)^{*}\end{array}$ & $\begin{array}{l}8.82 \pm 1.47^{b} \\
(2.78 \% \downarrow)^{*}\end{array}$ & $\begin{array}{l}10.57 \pm 2.10^{c} \\
(16.49 \% \uparrow \uparrow)^{*}\end{array}$ & $\begin{array}{l}10.50 \pm 1.51^{\mathrm{d}} \\
(15.71 \% \uparrow)^{*}\end{array}$ & $\begin{array}{l}9.20 \pm 1.78^{\mathrm{e}} \\
(1.40 \% \uparrow)^{*}\end{array}$ \\
\hline Forestomach & $11.11 \pm 1.42$ & $\begin{array}{l}17.03 \pm 3.80^{\mathrm{a}} \\
(53.26 \% \uparrow)^{*}\end{array}$ & $\begin{array}{l}13.35 \pm 3.59^{\mathrm{b}} \\
(20.19 \% \uparrow)^{*}\end{array}$ & $\begin{array}{l}12.58 \pm 2.66^{\mathrm{c}} \\
(13.22 \% \uparrow)^{*}\end{array}$ & $\begin{array}{l}14.62 \pm 2.71^{\mathrm{d}} \\
(31.64 \% \uparrow)^{*}\end{array}$ & $\begin{array}{l}16.16 \pm 3.91^{\mathrm{e}} \\
(45.48 \% \uparrow)^{*}\end{array}$ \\
\hline Heart & $8.84 \pm 1.26$ & $\begin{array}{l}10.36 \pm 2.07^{\mathrm{a}} \\
(17.19 \% \uparrow)^{*}\end{array}$ & $\begin{array}{l}9.32 \pm 1.66^{\mathrm{b}} \\
(5.51 \% \uparrow)^{*}\end{array}$ & $\begin{array}{l}10.36 \pm 1.72^{c} \\
(17.18 \% \uparrow \uparrow)^{*}\end{array}$ & $\begin{array}{l}10.86 \pm 1.34^{\mathrm{d}} \\
(22.92 \% \uparrow)^{*}\end{array}$ & $\begin{array}{l}10.14 \pm 1.03^{e} \\
(14.78 \% \uparrow)^{*}\end{array}$ \\
\hline Brain & $9.06 \pm 1.59$ & $\begin{array}{l}9.29 \pm 1.03^{\mathrm{a}} \\
(2.57 \% \uparrow)^{*}\end{array}$ & $\begin{array}{l}8.71 \pm 0.98^{\mathrm{b}} \\
(3.86 \% \downarrow)^{*}\end{array}$ & $\begin{array}{l}9.35 \pm 1.56^{\mathrm{c}} \\
(3.26 \% \uparrow)^{*}\end{array}$ & $\begin{array}{l}9.06 \pm 1.60^{\mathrm{d}} \\
(0.01 \% \uparrow)^{*}\end{array}$ & $\begin{array}{l}10.62 \pm 1.60^{\mathrm{e}} \\
(17.29 \% \uparrow \uparrow)^{*}\end{array}$ \\
\hline
\end{tabular}

*Data were expressed as mean \pm SEM of triplicate assays and significant difference from control values. Significant differences between dose groups and control were assayed by the use of ANOVA, $(p<0.05)$.

activities were found to be highly compatible (National Toxicology Program, 2006). According to these results, EULA and EUFA had a harmonious effect on AH, EROD, NNDNO, cyt.P450 and cyt. $\underline{b}_{5}$ activities and showed that they are able to very effective in detoxification mechanism of liver. The possible mechanisms of detoxification against toxicity by EULA and EUFA are due to significant modulation of phase I and II enzymes. The effects of the extracts on these modulating parameters can increase carcinogenic detoxification. These effects may also be due to the presence of phenolics, flavonoids and lycopene. Polyphenols and lycopene have been reported to protect potential external sources of free radicals against the threats (Kuhad, Sethi, Chopra, 2008; Sharma, 2013). 
Table IV was exhibited the changes in GST activities of experimental groups of mice liver, kidney, lung, forestomach, heart and brain. GST activities at different doses of EUFA and EULA-treated groups enhanced in kidney, forestomach, heart, brain and exhibited in a dosedependent manner $(p<0.05)$.

The mice treated with EUFA and EULA at low and high doses were found an increase in the DTD activities in cytosolic fraction of kidney, forestomach and heart (Table $\mathrm{V}$ ) and enhanced in the dose dependent modulation. The activity treated with low of EUFA and EULA extracts was an evident increase in hepatic and extrahepatic, significantly $(p<0.05)$. GST and DTD activities of BHA, treated animals were significantly increased in the all tissues (Table IV and V).

GST is a detoxification enzyme that is an important function in the coagulation of endogenous ligands (reducing glutathione). GST is effective in protecting against different cytotoxic, mutagenic and carcinogenic chemicals (Lodhi et al., 2014). DTD is the enzyme that is used to determine the effect of many anticancerogenic substrates. DTD protects against the toxic effect of kinons and metabolites (benzene, aromatic hydrocarbon, hydroquinone, etc.). DTD facilitates the elimination of the semiquinone radical and the bioactive metabolism of kinin. DTD has the property of protecting the quinone from reactive oxidation intermediates resulting from the oxidation of two electrons (Deepalakshmi, Mirunalini, 2013). The GST and DTD activities in the kidney, lung heart, brain and forestomach were determined. Under experimental conditions, applications of two different doses of EULA and EUFA were observed to significantly increase GST and DTD activities in the liver. The treatment of two different doses of EULA and EUFA observed increases in liver, kidney, lung, forestomach, heart, and forestomach in GST activities and kidney, forestomach, and heart in DTD activities.

The contents of T-SH, NP-SH and PB-SH were determined in liver homogenate to characterize oxidative status of mice in the hepatic cell and assess endogenous antioxidant defenses (Table VI). In all extracts-treated and BHA groups, the amounts of T-SH, NP-SH and PB-SH were significantly higher than the control group $(p<0.05)$. Furthermore, the T-SH, NP-SH and PB-SH levels of Group II, III, IV and V were found higher than in BHA-treated group.

Cytosolic LDH has been widely used to evaluate cell viability and membrane integrity is active. To further investigate the protective effect of EUFA and EULA, this study was performed the LDH release assay. As shown in Table VI, there was a significant increase of LDH activity into medium in Group II, III, IV and V compared to the untreated Group I.

For studying the moderation of the EULA and EUFA, the activities of G6PD and 6PGD activity were measured in liver (Table VI). G6PD and 6PGD activities in Group II and V were increased at low and high doses $(p<0.05)$ and also decreased their activities of Group III, IV and VI at both of doses, significantly $(p<0.05)$.

Table VII, VIII, IX and X were exhibited the effects of EUFA and EULA treatment on the levels of SOD,

TABLE V - Impact of EUFA, EULA and BHA on DTD activity in mice

\begin{tabular}{|c|c|c|c|c|c|c|}
\hline \multirow{2}{*}{$\begin{array}{l}\text { XME (phase II) } \\
\text { DTD (pmole/ } \\
\mathrm{min} / \mathrm{mg})\end{array}$} & \multirow[b]{2}{*}{ Control } & \multicolumn{5}{|c|}{ Treatment (fourteen days) } \\
\hline & & $\begin{array}{c}\text { EUFA } \\
(50 \mathrm{mg} / \mathrm{kg} \text { b.w. })\end{array}$ & $\begin{array}{c}\text { EUFA } \\
(100 \mathrm{mg} / \mathrm{kg} \text { b.w. }) \\
\end{array}$ & $\begin{array}{c}\text { EULA } \\
(50 \mathrm{mg} / \mathrm{kg} \text { b.w. })\end{array}$ & $\begin{array}{c}\text { EULA } \\
(100 \mathrm{mg} / \mathrm{kg} \text { b.w. })\end{array}$ & $\begin{array}{c}\text { BHA } \\
(0.75 \% \text { in diet })\end{array}$ \\
\hline Liver & $21.41 \pm 6.61$ & $\begin{array}{l}37.88 \pm 5.05^{\mathrm{a}} \\
(75.24 \% \uparrow)^{*}\end{array}$ & $\begin{array}{c}2.0 .47 \pm 4.13^{\mathrm{b}} \\
(5.30 \% \downarrow)^{*}\end{array}$ & $\begin{array}{l}18.10 \pm 4.68^{c} \\
(16.29 \% \downarrow)^{*}\end{array}$ & $\begin{array}{l}26.43 \pm 7.22^{\mathrm{d}} \\
(22.28 \% \uparrow)^{*}\end{array}$ & $\begin{array}{l}38.41 \pm 4.36^{\mathrm{e}} \\
(77.69 \% \uparrow)^{*}\end{array}$ \\
\hline Kidney & $12.72 \pm 6.01$ & $\begin{array}{l}17.19 \pm 3.77^{\mathrm{a}} \\
(35.10 \% \uparrow)^{*}\end{array}$ & $\begin{array}{l}22.53 \pm 8.07^{\mathrm{b}} \\
(77.06 \% \uparrow \uparrow)^{*}\end{array}$ & $\begin{array}{l}14.27 \pm 6.69^{c} \\
(12.13 \% \uparrow)^{*}\end{array}$ & $\begin{array}{l}36.76 \pm 15.28^{\mathrm{d}} \\
(188.94 \% \uparrow)^{*}\end{array}$ & $\begin{array}{l}33.40 \pm 13.36^{\mathrm{e}} \\
(162.51 \% \uparrow)^{*}\end{array}$ \\
\hline Lung & $61.15 \pm 7.92$ & $\begin{array}{c}82.14 \pm 36.15^{\mathrm{a}} \\
(34.31 \% \uparrow)^{*}\end{array}$ & $\begin{array}{c}49.38 \pm 14.80^{\mathrm{b}} \\
(19.25 \% \downarrow)^{*}\end{array}$ & $\begin{array}{l}43.12 \pm 9.63^{c} \\
(29.49 \% \downarrow)^{*}\end{array}$ & $\begin{array}{l}39.38 \pm 7.27^{\mathrm{d}} \\
(35.60 \% \downarrow)^{*}\end{array}$ & $\begin{array}{c}10.07 \pm 27.32^{\mathrm{e}} \\
(64.68 \% \uparrow)^{*}\end{array}$ \\
\hline Forestomach & $86.25 \pm 19.68$ & $\begin{array}{c}214.97 \pm 93.76^{\mathrm{a}} \\
(149.24 \% \uparrow)^{*}\end{array}$ & $\begin{array}{c}139.11 \pm 25.41^{\mathrm{b}} \\
(61.29 \% \uparrow)^{*}\end{array}$ & $\begin{array}{c}149.83 \pm 21.21^{\mathrm{c}} \\
(73.72 \% \uparrow \uparrow *\end{array}$ & $\begin{array}{c}162.83 \pm 87.26^{\mathrm{d}} \\
(88.80 \% \uparrow)^{*}\end{array}$ & $\begin{array}{c}193.32 \pm 51.82^{\mathrm{e}} \\
(124.14 \% \uparrow)^{*}\end{array}$ \\
\hline Heart & $33.93 \pm 9.79$ & $\begin{array}{l}78.21 \pm 20.88^{\mathrm{a}} \\
(130.53 \% \uparrow)^{*}\end{array}$ & $\begin{array}{l}40.27 \pm 8.89^{b} \\
(18.68 \% \uparrow)^{*}\end{array}$ & $\begin{array}{l}42.62 \pm 6.21^{\mathrm{c}} \\
(25.60 \% \uparrow)^{*}\end{array}$ & $\begin{array}{c}61.04 \pm 10.73^{\mathrm{d}} \\
(79.90 \% \uparrow)^{*}\end{array}$ & $\begin{array}{c}57.64 \pm 16.96^{\mathrm{e}} \\
(69.89 \% \uparrow)^{*}\end{array}$ \\
\hline Brain & $66.11 \pm 15.06$ & $\begin{array}{c}54.60 \pm 16.40^{\mathrm{a}} \\
(17.41 \% \downarrow)^{*}\end{array}$ & $\begin{array}{l}30.11 \pm 6.38^{\mathrm{b}} \\
(54.46 \% \downarrow)^{*}\end{array}$ & $\begin{array}{c}36.99 \pm 12.18^{\mathrm{c}} \\
(44.05 \% \downarrow)^{*}\end{array}$ & $\begin{array}{c}72.19 \pm 14.54^{\mathrm{d}} \\
(9.20 \% \uparrow)^{*}\end{array}$ & $\begin{array}{c}66.87 \pm 14.46^{\mathrm{e}} \\
(1.14 \% \uparrow)^{*}\end{array}$ \\
\hline
\end{tabular}

*Data were expressed as mean \pm SEM of triplicate assays and significant difference from control values. Significant differences between dose groups and control were assayed by the use of ANOVA, $(p<0.05)$. 
The impacts of Elaeagnus umbellata Thunb. leaf and fruit aqueous extracts on mice hepatic, extrahepatic antioxidant and drug metabolizing enzymes

TABLE VI - Impact of EUFA, EULA and BHA on T-SH, NP-SH, PB-SH, G6PD and 6PGD activities in mice

\begin{tabular}{|c|c|c|c|c|c|c|}
\hline \multirow{2}{*}{$\begin{array}{l}\text { XME } \\
\text { (Content or } \\
\text { enzymes) }\end{array}$} & \multirow[b]{2}{*}{ Control } & \multicolumn{5}{|c|}{ Treatment (fourteen days) } \\
\hline & & $\begin{array}{c}\text { EUFA } \\
(50 \mathrm{mg} / \mathrm{kg} \text { b.w. })\end{array}$ & $\begin{array}{c}\text { EUFA } \\
(100 \mathrm{mg} / \mathrm{kg} \text { b.w. })\end{array}$ & $\begin{array}{c}\text { EULA } \\
(50 \mathrm{mg} / \mathrm{kg} \text { b.w. }) \\
\end{array}$ & $\begin{array}{c}\text { EULA } \\
(100 \mathrm{mg} / \mathrm{kg} \text { b.w. })\end{array}$ & $\begin{array}{c}\text { BHA } \\
(0.75 \% \text { in diet }) \\
\end{array}$ \\
\hline $\begin{array}{l}\text { T-SH } \\
(\mu \mathrm{mole} / \mathrm{min} / \mathrm{mg})\end{array}$ & $163.68 \pm 18.77$ & $\begin{array}{c}192.80 \pm 28.92^{\mathrm{a}} \\
(17.79 \% \uparrow)^{*}\end{array}$ & $\begin{array}{c}192.34 \pm 39.18^{\mathrm{b}} \\
(17.51 \% \uparrow)^{*}\end{array}$ & $\begin{array}{c}237.75 \pm 23.10^{c} \\
(45.26 \% \uparrow)^{*}\end{array}$ & $\begin{array}{c}201.15 \pm 16.76^{\mathrm{d}} \\
(22.89 \% \uparrow)^{*}\end{array}$ & $\begin{array}{c}188.79 \pm 26.52^{\mathrm{e}} \\
(15.34 \% \uparrow)^{*}\end{array}$ \\
\hline $\begin{array}{l}\text { NP-SH } \\
(\mu \mathrm{mole} / \mathrm{min} / \mathrm{mg})\end{array}$ & $163.35 \pm 18.71$ & $\begin{array}{c}191.91 \pm 28.83^{\mathrm{a}} \\
(17.48 \% \uparrow)^{*}\end{array}$ & $\begin{array}{c}180.41 \pm 21.69^{\mathrm{b}} \\
(10.44 \% \uparrow)^{*}\end{array}$ & $\begin{array}{c}237.33 \pm 23.05^{\mathrm{c}} \\
(45.29 \% \uparrow)^{*}\end{array}$ & $\begin{array}{c}200.45 \pm 16.75^{\mathrm{d}} \\
(22.71 \% \uparrow)^{*}\end{array}$ & $\begin{array}{c}188.35 \pm 26.60^{\mathrm{e}} \\
(15.30 \% \uparrow)^{*}\end{array}$ \\
\hline $\begin{array}{l}\text { PB-SH } \\
(\mu \mathrm{mole} / \mathrm{min} / \mathrm{mg})\end{array}$ & $0.32 \pm 0.10$ & $\begin{array}{c}0.89 \pm 0.13^{\mathrm{a}} \\
(176.10 \% \uparrow)^{*}\end{array}$ & $\begin{array}{c}0.38 \pm 0.10^{\mathrm{b}} \\
(18.15 \% \uparrow)^{*}\end{array}$ & $\begin{array}{c}0.42 \pm 0.11^{\mathrm{c}} \\
(29.63 \% \uparrow)^{*}\end{array}$ & $\begin{array}{c}0.70 \pm 0.11^{\mathrm{d}} \\
(116.53 \% \uparrow)^{*}\end{array}$ & $\begin{array}{c}0.44 \pm 0.15^{\mathrm{e}} \\
(35.10 \% \uparrow)^{*}\end{array}$ \\
\hline $\begin{array}{l}\text { G6PD } \\
(\mathrm{nmole} / \mathrm{min} / \mathrm{mg})\end{array}$ & $0.42 \pm 0.13$ & $\begin{array}{l}0.45 \pm 0.10^{\mathrm{a}} \\
(1.07 \% \uparrow)^{*}\end{array}$ & $\begin{array}{c}0.32 \pm 0.09^{\mathrm{b}} \\
(23.59 \% \downarrow)^{*}\end{array}$ & $\begin{array}{l}0.43 \pm 0.08^{c} \\
(3.57 \% \uparrow)^{*}\end{array}$ & $\begin{array}{l}0.47 \pm 0.06^{\mathrm{d}} \\
(11.12 \% \uparrow)^{*}\end{array}$ & $\begin{array}{l}0.44 \pm 0.12^{\mathrm{e}} \\
(4.47 \% \uparrow)^{*}\end{array}$ \\
\hline $\begin{array}{l}\text { 6PGD } \\
\text { (nmole/min/mg) }\end{array}$ & $0.29 \pm 0.08$ & $\begin{array}{c}0.38 \pm 0.06^{\mathrm{a}} \\
(31.31 \% \uparrow)^{*}\end{array}$ & $\begin{array}{l}0.26 \pm 0.08^{\mathrm{b}} \\
(7.68 \% \downarrow)^{*}\end{array}$ & $\begin{array}{l}0.27 \pm 0.08^{\mathrm{c}} \\
(4.40 \% \downarrow)^{*}\end{array}$ & $\begin{array}{l}0.31 \pm 0.04^{\mathrm{d}} \\
(7.70 \% \uparrow)^{*}\end{array}$ & $\begin{array}{c}0.35 \pm 0.05^{\mathrm{e}} \\
(22.15 \% \uparrow)^{*}\end{array}$ \\
\hline $\begin{array}{l}\text { LDH } \\
(\mathrm{nmole} / \mathrm{min} / \mathrm{mg})\end{array}$ & $0.21 \pm 0.083$ & $\begin{array}{c}0.285 \pm 0.069^{\mathrm{a}} \\
(35.43 \% \uparrow)^{*}\end{array}$ & $\begin{array}{c}0.294 \pm 0.074^{b} \\
(39.49 \% \uparrow)^{*}\end{array}$ & $\begin{array}{l}0.325 \pm 0.78^{c} \\
(54.35 \% \uparrow)^{*}\end{array}$ & $\begin{array}{l}0.266 \pm 0.87^{d} \\
(26.36 \% \uparrow)^{*}\end{array}$ & $\begin{array}{c}0.215 \pm 0.67^{\mathrm{e}} \\
(2.05 \% \uparrow)^{*}\end{array}$ \\
\hline
\end{tabular}

*Data were expressed as mean \pm SEM of triplicate assays and significant difference from control values. Significant differences between dose groups and control were assayed by the use of ANOVA, $(p<0.05)$.

CAT, GR and GP activities and evaluated in the cytosolic fraction of hepatic and extrahepatic. These effects were comparable to BHA as a standard antioxidant.

A dose-dependent modulation in specific activities of SOD was evident in liver and the results were $40.56 \%$ $(p<0.05)$ in group IV and $0.26 \%(p<0.05)$ in group V. Kidney SOD activities in Group III, IV and V were increased by $39.92,1.93$ and $20.80 \%$, respectively when compared with Group I and VI. Kidney and heart SOD activities in Group II, III, IV and V were improved at low and high doses level $(p<0.05)$ relative to group I. BHA in Group VI enhanced the SOD activity significantly in forestomach and decreased significantly in liver, kidney, lung and brain (Table VII).

Oral application with 50 and $100 \mathrm{mg} / \mathrm{kg}$ of EULA and EUFA attenuated increases in the hepatic tissue and extrahepatic CAT activities. The activity of CAT in forestomach and brain exhibited a significant enhancement

TABLE VII - Impact of EUFA, EULA and BHA on SOD activity in mice

\begin{tabular}{|c|c|c|c|c|c|c|}
\hline \multirow{2}{*}{$\begin{array}{l}\text { Antioxidant } \\
\text { enzyme, } \\
\text { SOD (U/mg) }\end{array}$} & \multirow[b]{2}{*}{ Control } & \multicolumn{5}{|c|}{ Treatment (fourteen days) } \\
\hline & & $\begin{array}{c}\text { EUFA } \\
(50 \mathrm{mg} / \mathrm{kg} \text { b.w. }) \\
\end{array}$ & $\begin{array}{c}\text { EUFA } \\
(100 \mathrm{mg} / \mathrm{kg} \text { b.w. })\end{array}$ & $\begin{array}{c}\text { EULA } \\
(50 \mathrm{mg} / \mathrm{kg} \text { b.w. }) \\
\end{array}$ & $\begin{array}{c}\text { EULA } \\
(100 \mathrm{mg} / \mathrm{kg} \text { b.w. })\end{array}$ & $\begin{array}{c}\text { BHA } \\
(0.75 \% \text { in diet }) \\
\end{array}$ \\
\hline Liver & $11.62 \pm 3.80^{\mathrm{a}}$ & $\begin{array}{l}7.41 \pm 3.35^{\mathrm{ab}} \\
(36.23 \% \downarrow)^{*}\end{array}$ & $\begin{array}{c}6.46 \pm 2.06^{\mathrm{b}} \\
(44.42 \% \downarrow)^{*}\end{array}$ & $\begin{array}{l}16.34 \pm 2.89^{\mathrm{ab}} \\
(40.56 \% \uparrow)^{*}\end{array}$ & $\begin{array}{c}11.65 \pm 1.46^{\mathrm{ab}} \\
(0.26 \% \uparrow)^{*}\end{array}$ & $\begin{array}{c}9.03 \pm 2.79^{\mathrm{ab}} \\
(22.29 \% \downarrow)^{*}\end{array}$ \\
\hline Kidney & $5.18 \pm 1.66^{\mathrm{a}}$ & $\begin{array}{l}4.81 \pm 2.10^{\mathrm{a}} \\
(7.14 \% \downarrow)^{*}\end{array}$ & $\begin{array}{c}7.25 \pm 3.06^{\mathrm{a}} \\
(39.92 \% \uparrow)^{*}\end{array}$ & $\begin{array}{l}5.28 \pm 1.39^{\mathrm{a}} \\
(1.93 \% \uparrow)^{*}\end{array}$ & $\begin{array}{c}6.26 \pm 2.67^{\mathrm{a}} \\
(20.80 \% \uparrow)^{*}\end{array}$ & $\begin{array}{c}3.06 \pm 1.90^{\alpha} \\
(40.93 \% \downarrow)^{*}\end{array}$ \\
\hline Lung & $7.01 \pm 1.9^{\mathrm{a}}$ & $\begin{array}{l}5.19 \pm 1.65^{\mathrm{ab}} \\
(13.32 \% \downarrow)^{*}\end{array}$ & $\begin{array}{l}5.94 \pm 1.88^{\mathrm{ab}} \\
(10.30 \% \downarrow)^{*}\end{array}$ & $\begin{array}{c}5.32 \pm 1.6^{\mathrm{ab}} \\
(37.82 \% \downarrow)^{*}\end{array}$ & $\begin{array}{l}4.44 \pm 2.21^{\mathrm{ab}} \\
(32.00 \% \downarrow)^{*}\end{array}$ & $\begin{array}{c}1.19 \pm 0.74^{\mathrm{b}} \\
(84.69 \% \downarrow)^{*}\end{array}$ \\
\hline Forestomach & $12.37 \pm 1.76^{\mathrm{a}}$ & $\begin{array}{c}4.91 \pm 1.8^{\mathrm{b}} \\
(60.31 \% \downarrow)^{*}\end{array}$ & $\begin{array}{c}4.8 \pm 1.92^{\mathrm{b}} \\
(61.23 \% \downarrow)^{*}\end{array}$ & $\begin{array}{l}9.23 \pm 1.85^{\mathrm{ab}} \\
(25.38 \% \downarrow)^{*}\end{array}$ & $\begin{array}{l}18.98 \pm 1.65^{\mathrm{b}} \\
(53.44 \% \uparrow)^{*}\end{array}$ & $\begin{array}{l}20.97 \pm 1.92^{\mathrm{b}} \\
(69.52 \% \uparrow)^{*}\end{array}$ \\
\hline Heart & $12.22 \pm 1.67^{\mathrm{a}}$ & $\begin{array}{l}22.93 \pm 2.49^{b} \\
(87.64 \% \uparrow)^{*}\end{array}$ & $\begin{array}{l}13.49 \pm 1.67^{\mathrm{ab}} \\
(10.39 \% \uparrow)^{*}\end{array}$ & $\begin{array}{c}13.11 \pm 3^{\mathrm{ab}} \\
(7.28 \% \uparrow)^{*}\end{array}$ & $\begin{array}{c}13.24 \pm 2.96^{\mathrm{ab}} \\
(8.35 \% \uparrow)^{*}\end{array}$ & $\begin{array}{c}26.10 \pm 2.95^{b} \\
(113.75 \% \uparrow)^{*}\end{array}$ \\
\hline Brain & $5.89 \pm 2.95^{\mathrm{a}}$ & $\begin{array}{l}2.33 \pm 1.16^{\mathrm{ab}} \\
(60.44 \% \downarrow)^{*}\end{array}$ & $\begin{array}{l}1.35 \pm 0.35^{\mathrm{ab}} \\
(78.9 \% \downarrow)^{*}\end{array}$ & $\begin{array}{l}9.44 \pm 5.09^{\mathrm{ab}} \\
(60.27 \% \uparrow)^{*}\end{array}$ & $\begin{array}{c}3.06 \pm 1.61^{\mathrm{b}} \\
(48.22 \% \downarrow)^{*}\end{array}$ & $\begin{array}{l}2.07 \pm 0.46^{\mathrm{ab}} \\
(61.97 \% \downarrow)^{*}\end{array}$ \\
\hline
\end{tabular}

*Data were expressed as mean \pm SEM of triplicate assays and significant difference from control values. Significant differences between dose groups and control were assayed by the use of ANOVA, $(p<0.05)$. 
at low and high doses relatived to Group I (Table VIII). EULA and EUFA extracts enhanced CAT activity in Group IV (liver), III (kidney), IV (kidney), V (lung) and III (heart).

The low and high doses of EULA and EUFA caused significant alterations in liver (Group V), kidney (Group II), heart (Group II and III) and brain (Group II) GP level when compared to that of the untreated in Group I, $p<0.05$ (Table IX).
Table $\mathrm{X}$ shows the effects of oral application with 50 and $100 \mathrm{mg} / \mathrm{kg}$ of EULA and EUFA on the GR. The Group II, III and V animals had significantly increased in liver and kidney.

One of the most important markers of hepatic and extrahepatic cell damage is a decrease in the level of SOD enzyme activity (Dorman et al., 2003). SOD is one of the vital enzymes in the antioxidant defense systems in vivo and diminishes the toxic $\mathrm{O}_{2}{ }^{-}$by converting it into $\mathrm{H}_{2} \mathrm{O}_{2}$.

TABLE VIII - Impact of EUFA, EULA and BHA on CAT activity in mice

\begin{tabular}{|c|c|c|c|c|c|c|}
\hline \multirow{2}{*}{$\begin{array}{l}\text { Antioxidant } \\
\text { enzyme, } \\
\text { CAT (U/mg) }\end{array}$} & \multirow[b]{2}{*}{ Control } & \multicolumn{5}{|c|}{ Treatment (fourteen days) } \\
\hline & & $\begin{array}{c}\text { EUFA } \\
(50 \mathrm{mg} / \mathrm{kg} \mathrm{b.w.})\end{array}$ & $\begin{array}{c}\text { EUFA } \\
(100 \mathrm{mg} / \mathrm{kg} \text { b.w. })\end{array}$ & $\begin{array}{c}\text { EULA } \\
(50 \mathrm{mg} / \mathrm{kg} \mathrm{b.w.)}\end{array}$ & $\begin{array}{c}\text { EULA } \\
(100 \mathrm{mg} / \mathrm{kg} \mathrm{b.w.)}\end{array}$ & $\begin{array}{c}\text { BHA } \\
\text { (0.75\% in diet) }\end{array}$ \\
\hline Liver & $0.14 \pm 0.02^{\mathrm{a}}$ & $\begin{array}{c}0.10 \pm 0.01^{\mathrm{b}} \\
(37.52 \% \downarrow)^{*}\end{array}$ & $\begin{array}{l}\left(0.13 \pm 0.00^{\mathrm{b}}\right. \\
(12.54 \% \downarrow)^{*}\end{array}$ & $\begin{array}{l}0.17 \pm 0.02^{\mathrm{ab}} \\
(17.36 \% \uparrow)^{*}\end{array}$ & $\begin{array}{l}0.13 \pm 0.011^{\mathrm{ab}} \\
(12.52 \% \downarrow)^{*}\end{array}$ & $\begin{array}{c}0.14 \pm 0.048^{\mathrm{ab}} \\
(2.14 \% \downarrow)^{*}\end{array}$ \\
\hline Kidney & $0.20 \pm 0.04^{\mathrm{a}}$ & $\begin{array}{l}0.15 \pm 0.017^{\mathrm{a}} \\
(26.50 \% \downarrow)^{*}\end{array}$ & $\begin{array}{c}0.26 \pm 0.05^{\mathrm{a}} \\
(30.00 \% \uparrow)^{*}\end{array}$ & $\begin{array}{c}0.24 \pm 0.03^{\mathrm{a}} \\
(20.00 \% \uparrow)^{*}\end{array}$ & $\begin{array}{l}0.12 \pm 0.011^{\mathrm{a}} \\
(42.00 \% \downarrow)^{*}\end{array}$ & $\begin{array}{l}0.19 \pm 0.02^{\mathrm{a}} \\
(5.00 \% \downarrow)^{*}\end{array}$ \\
\hline Lung & $0.05 \pm 0.00^{\mathrm{a}}$ & $\begin{array}{l}0.015 \pm 0.00^{\mathrm{b}} \\
(70.00 \% \downarrow)^{*}\end{array}$ & $\begin{array}{c}0.05 \pm 0.00^{\mathrm{ab}} \\
(0.00 \%)^{*}\end{array}$ & $\begin{array}{l}0.04 \pm 0.00^{\mathrm{ab}} \\
(28.00 \% \downarrow)^{*}\end{array}$ & $\begin{array}{l}0.07 \pm 0.02^{\mathrm{ab}} \\
(32.00 \% \uparrow)^{*}\end{array}$ & $\begin{array}{l}0.02 \pm 0.011^{\mathrm{ab}} \\
(58.00 \% \downarrow)^{*}\end{array}$ \\
\hline Forestomach & $0.02 \pm 0.00^{\mathrm{a}}$ & $\begin{array}{l}0.03 \pm 0.001^{\mathrm{a}} \\
(72.20 \% \uparrow)^{*}\end{array}$ & $\begin{array}{c}0.02 \pm 0.00^{\mathrm{a}} \\
(11.14 \% \uparrow)^{*}\end{array}$ & $\begin{array}{l}0.02 \pm 0.001^{\mathrm{a}} \\
(16.72 \% \uparrow)^{*}\end{array}$ & $\begin{array}{l}0.028 \pm 0.01^{\mathrm{a}} \\
(55.65 \% \uparrow)^{*}\end{array}$ & $\begin{array}{c}0.015 \pm 0.025^{\mathrm{a}} \\
(16.72 \% \downarrow)^{*}\end{array}$ \\
\hline Heart & $0.09 \pm 0.03^{\mathrm{a}}$ & $\begin{array}{l}0.031 \pm 0.00^{\mathrm{ab}} \\
(53.82 \% \downarrow)^{*}\end{array}$ & $\begin{array}{c}0.02 \pm 0.001^{\mathrm{b}} \\
(4.92 \% \uparrow)^{*}\end{array}$ & $\begin{array}{c}0.02 \pm 0.00^{\mathrm{b}} \\
(36.87 \% \downarrow)^{*}\end{array}$ & $\begin{array}{c}0.02 \pm 0.00^{\mathrm{b}} \\
(30.93 \% \downarrow)^{*}\end{array}$ & $\begin{array}{c}0.061 \pm 0.003^{\mathrm{ab}} \\
(26.41 \% \downarrow)^{*}\end{array}$ \\
\hline Brain & $0.03 \pm 0.00^{\mathrm{a}}$ & $\begin{array}{c}0.08 \pm 0.01^{\mathrm{ab}} \\
(166.00 \% \uparrow)^{*}\end{array}$ & $\begin{array}{c}0.06 \pm 0.01^{\mathrm{ab}} \\
(100.00 \% \uparrow)^{*}\end{array}$ & $\begin{array}{c}0.05 \pm 0.00^{\mathrm{b}} \\
(63.32 \% \uparrow)^{*}\end{array}$ & $\begin{array}{l}0.01 \pm 0.00^{\mathrm{ab}} \\
(80.00 \% \downarrow)^{*}\end{array}$ & $\begin{array}{c}0.02 \pm 0.00^{\mathrm{ab}} \\
(33.32 \% \downarrow)^{*}\end{array}$ \\
\hline
\end{tabular}

*Data were expressed as mean \pm SEM of triplicate assays and significant difference from control values. Significant differences between dose groups and control were assayed by the use of ANOVA, $(p<0.05)$.

TABLE IX - Impact of of EUFA, EULA and BHA on glutathione peroxidase (GP) activity in mice

\begin{tabular}{|c|c|c|c|c|c|c|}
\hline \multirow{2}{*}{$\begin{array}{l}\text { Antioxidant } \\
\text { enzyme, GP } \\
(\text { nmole } / \mathrm{min} / \mathrm{mg})\end{array}$} & \multirow[b]{2}{*}{ Control } & \multicolumn{5}{|c|}{ Treatment (fourteen days) } \\
\hline & & $\begin{array}{c}\text { EUFA } \\
(50 \mathrm{mg} / \mathrm{kg} \text { b.w. })\end{array}$ & $\begin{array}{c}\text { EUFA } \\
(100 \mathrm{mg} / \mathrm{kg} \text { b.w. })\end{array}$ & $\begin{array}{c}\text { EULA } \\
(50 \mathrm{mg} / \mathrm{kg} \mathrm{b.w.)}) \\
\end{array}$ & $\begin{array}{c}\text { EULA } \\
(100 \mathrm{mg} / \mathrm{kg} \text { b.w. })\end{array}$ & $\begin{array}{c}\text { BHA } \\
\text { (0.75\% in diet) } \\
\end{array}$ \\
\hline Liver & $11.23 \pm 3.02^{\mathrm{a}}$ & $\begin{array}{c}5.04 \pm 1.85^{\mathrm{b}} \\
(55.12 \% \downarrow)^{*}\end{array}$ & $\begin{array}{c}5.44 \pm 2.05^{\mathrm{ab}} \\
(51.56 \% \downarrow)^{*}\end{array}$ & $\begin{array}{l}8.09 \pm 2.41^{\mathrm{ab}} \\
(27.96 \% \downarrow)^{*}\end{array}$ & $\begin{array}{l}14.08 \pm 3.74^{\mathrm{ab}} \\
(25.38 \% \uparrow)^{*}\end{array}$ & $\begin{array}{l}19.77 \pm 4.54^{\text {ab }} \\
(76.04 \% \uparrow)^{*}\end{array}$ \\
\hline Kidney & $12.84 \pm 2.61^{\mathrm{a}}$ & $\begin{array}{c}13.05 \pm 5.06^{\mathrm{ab}} \\
(1.64 \% \uparrow)^{*}\end{array}$ & $\begin{array}{c}5.25 \pm 1.6^{\mathrm{b}} \\
(59.11 \% \downarrow)^{*}\end{array}$ & $\begin{array}{c}5.80 \pm 1.89^{\mathrm{b}} \\
(54.83 \% \downarrow)^{*}\end{array}$ & $\begin{array}{c}5.38 \pm 2.74^{\mathrm{b}} \\
(58.10 \% \downarrow)^{*}\end{array}$ & $\begin{array}{c}12.64 \pm 2.34^{\mathrm{ab}} \\
(1.56 \% \downarrow)^{*}\end{array}$ \\
\hline Lung & $9.19 \pm 2.77^{\mathrm{a}}$ & $\begin{array}{c}6.26 \pm 2.25^{\mathrm{b}} \\
(31.88 \% \downarrow)^{*}\end{array}$ & $\begin{array}{c}3.71 \pm 0.78^{\mathrm{b}} \\
(59.63 \% \downarrow)^{*}\end{array}$ & $\begin{array}{c}3.22 \pm 1.06^{\mathrm{b}} \\
(64.54 \% \downarrow)^{*}\end{array}$ & $\begin{array}{c}4.28 \pm 1.81^{\mathrm{b}} \\
(53.42 \% \downarrow)^{*}\end{array}$ & $\begin{array}{c}6.23 \pm 1.92^{\mathrm{b}} \\
(32.21 \% \downarrow)^{*}\end{array}$ \\
\hline Forestomach & $3.58 \pm 1.44^{\mathrm{a}}$ & $\begin{array}{l}3.461 .13^{\mathrm{ab}} \\
(3.35 \% \downarrow)^{*}\end{array}$ & $\begin{array}{l}2.12 \pm 1.19^{\mathrm{ab}} \\
(34.36 \% \downarrow)^{*}\end{array}$ & $\begin{array}{c}1.40 \pm 0.72^{\mathrm{b}} \\
(60.89 \% \downarrow)^{*}\end{array}$ & $\begin{array}{c}1.68 \pm 1.32^{\mathrm{b}} \\
(53.07 \% \downarrow)^{*}\end{array}$ & $\begin{array}{l}3.22 \pm 1.16^{\mathrm{ab}} \\
(10.06 \% \downarrow)^{*}\end{array}$ \\
\hline Heart & $1.69 \pm 0.44^{\mathrm{a}}$ & $\begin{array}{c}4.22 \pm 1.28^{\mathrm{b}} \\
(149.72 \% \uparrow)^{*}\end{array}$ & $\begin{array}{l}2.56 \pm 1.40^{\mathrm{ab}} \\
(51.48 \% \uparrow)^{*}\end{array}$ & $\begin{array}{l}1.63 \pm 0.6^{\mathrm{ab}} \\
(3.68 \% \downarrow)^{*}\end{array}$ & $\begin{array}{l}1.48 \pm 0.65^{\mathrm{ab}} \\
(12.43 \% \downarrow)^{*}\end{array}$ & $\begin{array}{l}2.92 \pm 0.63^{\mathrm{ab}} \\
(72.78 \% \uparrow)^{*}\end{array}$ \\
\hline Brain & $3.24 \pm 1.31^{\mathrm{a}}$ & $\begin{array}{l}3.53 \pm 3.03^{\mathrm{a}} \\
(8.95 \% \uparrow)^{*}\end{array}$ & $\begin{array}{c}2.82 \pm 0.97^{\mathrm{a}} \\
(12.96 \% \downarrow)^{*}\end{array}$ & $\begin{array}{c}2.71 \pm 06^{\mathrm{a}} \\
(13.36 \% \downarrow)^{*}\end{array}$ & $\begin{array}{c}1.18 \pm 0.58^{\mathrm{a}} \\
(63.59 \% \downarrow)^{*}\end{array}$ & $\begin{array}{l}4.13 \pm 1.23^{\mathrm{a}} \\
(27.47 \% \uparrow)^{*}\end{array}$ \\
\hline
\end{tabular}

*Data were expressed as mean \pm SEM of triplicate assays and significant difference from control values. Significant differences between dose groups and control were assayed by the use of ANOVA, $(p<0.05)$. 
The impacts of Elaeagnus umbellata Thunb. leaf and fruit aqueous extracts on mice hepatic, extrahepatic antioxidant and drug metabolizing enzymes

TABLE X - Impact of EUFA, EULA and BHA on glutathione reductase (GR) activity in mice

\begin{tabular}{|c|c|c|c|c|c|c|}
\hline \multirow{2}{*}{$\begin{array}{l}\text { Antioxidant } \\
\text { enzyme, GR } \\
\text { (nmole/min/mg) }\end{array}$} & \multirow[b]{2}{*}{ Control } & \multicolumn{5}{|c|}{ Treatment (fourteen days) } \\
\hline & & $\begin{array}{c}\text { EUFA } \\
(50 \mathrm{mg} / \mathrm{kg} \text { b.w. }) \\
\end{array}$ & $\begin{array}{c}\text { EUFA } \\
(100 \mathrm{mg} / \mathrm{kg} \text { b.w. })\end{array}$ & $\begin{array}{c}\text { EULA } \\
(50 \mathrm{mg} / \mathrm{kg} \text { b.w. }) \\
\end{array}$ & $\begin{array}{c}\text { EULA } \\
(100 \mathrm{mg} / \mathrm{kg} \mathrm{b.w.)})\end{array}$ & $\begin{array}{c}\text { BHA } \\
\text { (0.75\% in diet) } \\
\end{array}$ \\
\hline Liver & $1.82 \pm 0.65^{\mathrm{a}}$ & $\begin{array}{l}1.76 \pm 0.29^{a} \\
(4.25 \% \uparrow)^{*}\end{array}$ & $\begin{array}{c}2.51 \pm 0.45^{\mathrm{a}} \\
(37.92 \% \uparrow)^{*}\end{array}$ & $\begin{array}{c}1.27 \pm 0.56^{\mathrm{a}} \\
(30.22 \% \downarrow)^{*}\end{array}$ & $\begin{array}{c}1.25 \pm 0.22^{\mathrm{a}} \\
(31.32 \% \downarrow)^{*}\end{array}$ & $\begin{array}{l}1.74 \pm 0.20^{\mathrm{a}} \\
(4.39 \% \downarrow)^{*}\end{array}$ \\
\hline Kidney & $1.85 \pm 0.19^{\mathrm{a}}$ & $\begin{array}{c}1.56 \pm 0.29^{\mathrm{a}} \\
(15.68 \% \downarrow)^{*}\end{array}$ & $\begin{array}{c}2.56 \pm 0.39^{\mathrm{a}} \\
(38.38 \% \uparrow)^{*}\end{array}$ & $\begin{array}{l}1.74 \pm 0.37^{\mathrm{a}} \\
(5.94 \% \downarrow)^{*}\end{array}$ & $\begin{array}{c}2.61 \pm 1.37^{\mathrm{a}} \\
(41.08 \% \uparrow)^{*}\end{array}$ & $\begin{array}{c}2.93 \pm 0.56^{\mathrm{a}} \\
(58.38 \% \uparrow)^{*}\end{array}$ \\
\hline Lung & $2.09 \pm 0.67^{\mathrm{a}}$ & $\begin{array}{c}1.15 \pm 0.29^{\mathrm{a}} \\
(81.74 \% \downarrow)^{*}\end{array}$ & $\begin{array}{c}1.34 \pm 0.68^{\mathrm{a}} \\
(40.76 \% \downarrow)^{*}\end{array}$ & $\begin{array}{c}1.40 \pm 0.62^{\mathrm{a}} \\
(33.01 \% \downarrow)^{*}\end{array}$ & $\begin{array}{c}1.26 \pm 0.48^{\mathrm{a}} \\
(39.71 \% \downarrow)^{*}\end{array}$ & $\begin{array}{c}1.76 \pm 0.77^{\mathrm{a}} \\
(15.79 \% \uparrow)^{*}\end{array}$ \\
\hline Forestomach & $1.42 \pm 0.52^{\mathrm{a}}$ & $\begin{array}{c}1.09 \pm 0.60^{\mathrm{a}} \\
(23.24 \% \downarrow)^{*}\end{array}$ & $\begin{array}{c}1.04 \pm 0.34^{\mathrm{a}} \\
(26.76 \% \downarrow)^{*}\end{array}$ & $\begin{array}{l}1.39 \pm 0.25^{\mathrm{a}} \\
(2.11 \% \downarrow)^{*}\end{array}$ & $\begin{array}{c}1.04 \pm 0.34^{\mathrm{a}} \\
(26.76 \% \downarrow)^{*}\end{array}$ & $\begin{array}{c}1.6 \pm 0.48^{\mathrm{a}} \\
(12.68 \% \uparrow)^{*}\end{array}$ \\
\hline Heart & $3.77 \pm 0.92^{\mathrm{a}}$ & $\begin{array}{l}2.31 \pm 0.73^{\mathrm{ab}} \\
(38.73 \% \downarrow)^{*}\end{array}$ & $\begin{array}{c}2.28 \pm 0.74^{\mathrm{b}} \\
(39.52 \% \downarrow)^{*}\end{array}$ & $\begin{array}{c}1.59 \pm 0.67^{\mathrm{b}} \\
(57.82 \% \downarrow)^{*}\end{array}$ & $\begin{array}{c}1.62 \pm 0.49^{\mathrm{b}} \\
(57.03 \% \downarrow)^{*}\end{array}$ & $\begin{array}{l}2.75 \pm 0.63^{\mathrm{b}} \\
(27.06 \% \downarrow)^{*}\end{array}$ \\
\hline Brain & $1.84 \pm 0.52^{\mathrm{a}}$ & $\begin{array}{l}1.61 \pm 0.55^{\mathrm{ab}} \\
(12.46 \% \downarrow)^{*}\end{array}$ & $\begin{array}{c}0.41 \pm 0.23^{\mathrm{b}} \\
(76.21 \% \downarrow)^{*}\end{array}$ & $\begin{array}{l}1.06 \pm 0.65^{\mathrm{ab}} \\
(42.39 \% \downarrow)^{*}\end{array}$ & $\begin{array}{l}1.22 \pm 0.49^{\mathrm{ab}} \\
(33.69 \% \downarrow)^{*}\end{array}$ & $\begin{array}{l}1.92 \pm 0.54^{\mathrm{ab}} \\
(4.34 \% \uparrow)^{*}\end{array}$ \\
\hline
\end{tabular}

*Data were expressed as mean \pm SEM of triplicate assays and significant difference from control values. Significant differences between dose groups and control were assayed by the use of ANOVA, $(p<0.05)$.

EULA and EUFA caused a significant increase in liver, kidney and heart SOD activity. Thus, the extracts reduce radicals induced oxidative damage and free radicals to liver, kidney, lung, brain, forestomach and heart. CAT is an antioxidant enzyme that exists commonly in all living tissues and shows the highest activity in tissues and red blood cells. CAT protects toxic hydrogen peroxide from high active hydroxyl radical damage of tissues. For this reason, the reduction of CAT activity may be due to many deleterious effects due to the removal of hydrogen peroxide and superoxide radicals. In this study, the standard BHA decreased in the CAT activity levels. The CAT activities of some organs in Groups II, III, IV, and V were reduced or increased. These changes in CAT activity may lead to reduced hepatic and extrahepatic damage. The enhancement in the SOD and CAT activities can be influenced the phytochemical contents of EULA and EUFA (Ozen et al., 2017).

Glutathione (GSH), a non-enzymatic antioxidant, is the most abundant tripeptide in the liver. GSH protects from superoxide radicals, ROS, hydrogen peroxide, and protein thiols of the membrane. EULA and EUFA significantly affected GST, GR and GP levels in dosedependent manner. Polyphenols (phenolics, flavonoids, anthocyanins, lycopene and other antioxidant substances) can be explained by phytochemical evaluation of EULA and EUFA extracts and supported antioxidant activities in tissues (Ozen et al., 2017).

The levels of LP in microsomal and cytosolic fractions were summarized in Table XI and exhibited inhibition by Group II, III, IV, V and VI as compared to the control. LP level of liver, lung, heart and brain in high dose of EUFA showed effective as compared control group. The level of MDA, the final disruption product of lipid peroxidation in the tissue, was found to enhance the antioxidant defense mechanisms against the oxidative stress and inhibit lipid peroxidation leading to tissue damage in EULA and EUFA-treated groups. The increase in MDA levels reveals increased LP leading to excessive free radical damage and is an indicative of the decline of the antioxidant defense mechanism. The LP is the source of many dangerous diseases such as cancer (Blot et al., 1993). In this study, LP in the fractions was induced by $\mathrm{Fe}^{3+}$ ascorbate. The LP inhibition of the EUFA and EULA-treated groups are apparent. Thus, aquous extracts can regulate cellular anomalies or chain reactions caused by cellular LP. The increase in SOD activity accelerates the dismutation of hydrogen peroxide and superoxide radicals by CAT (Glasauer, Chandel, 2014). Reduction of LP, coagulation by CAT and formation of superoxide in the experimental groups may be effective against cell damage of ROS.

In vivo study, it was observed that some enzymes of the phase I and II, LDH, level of LP and antioxidant parameters were moderated by oral administration of EULA and EUFA extracts in experimental animals. In all of these effects, it can be said that EULA and EUFA is probably effective in increasing carcinogenic detoxification.

Reducing the effect of reagent that affect the microsomal monooxygenase system can detoxify and 
TABLE XI - Impact of EUFA, EULA and BHA on LP in mice

\begin{tabular}{|c|c|c|c|c|c|c|}
\hline \multirow{2}{*}{$\begin{array}{l}\text { LP } \\
\text { (nmole/mg) }\end{array}$} & \multirow[b]{2}{*}{ Control } & \multicolumn{5}{|c|}{ Treatment (fourteen days) } \\
\hline & & $\begin{array}{c}\text { EUFA } \\
(50 \mathrm{mg} / \mathrm{kg} \text { b.w. })\end{array}$ & $\begin{array}{c}\text { EUFA } \\
(100 \mathrm{mg} / \mathrm{kg} \mathrm{b.w.)})\end{array}$ & $\begin{array}{c}\text { EULA } \\
(50 \mathrm{mg} / \mathrm{kg} \text { b.w. })\end{array}$ & $\begin{array}{c}\text { EULA } \\
(100 \mathrm{mg} / \mathrm{kg} \mathrm{b.w.)})\end{array}$ & $\begin{array}{c}\text { BHA } \\
(0.75 \% \text { in diet })\end{array}$ \\
\hline $\begin{array}{l}\text { Liver } \\
\text { (microsome) }\end{array}$ & $2.46 \pm 0.72$ & $\begin{array}{l}4.05 \pm 1.73^{\mathrm{a}} \\
(64.63 \% \uparrow)\end{array}$ & $\begin{array}{c}3.62 \pm 1.05^{\mathrm{b}} \\
(7.15 \% \uparrow)\end{array}$ & $\begin{array}{l}1.49 \pm 0.28^{c} \\
(39.43 \% \downarrow)\end{array}$ & $\begin{array}{l}1.65 \pm 0.29^{\mathrm{d}} \\
(32.93 \% \downarrow)\end{array}$ & $\begin{array}{c}2.68 \pm 0.43^{\mathrm{e}} \\
(8.94 \% \downarrow)\end{array}$ \\
\hline $\begin{array}{l}\text { Liver } \\
\text { (cytosol) }\end{array}$ & $1.27 \pm 0.25$ & $\begin{array}{c}1.29 \pm 0.25^{\mathrm{a}} \\
(1.57 \% \uparrow)\end{array}$ & $\begin{array}{c}0.95 \pm 0.36^{\mathrm{b}} \\
(25.2 \% \downarrow)\end{array}$ & $\begin{array}{l}4.07 \pm 1.62^{\mathrm{c}} \\
(20.47 \% \uparrow)\end{array}$ & $\begin{array}{l}1.51 \pm 0.61^{\mathrm{d}} \\
(18.89 \% \uparrow)\end{array}$ & $\begin{array}{l}1.65 \pm 0.54^{\mathrm{e}} \\
(29.92 \% \uparrow)\end{array}$ \\
\hline $\begin{array}{l}\text { Kidney } \\
\text { (cytosol) }\end{array}$ & $3.68 \pm 2.04$ & $\begin{array}{c}3.43 \pm 1.07^{\mathrm{a}} \\
(6.79 \% \downarrow)\end{array}$ & $\begin{array}{l}4.54 \pm 1.79^{\mathrm{b}} \\
(23.37 \% \uparrow)\end{array}$ & $\begin{array}{l}14.67 \pm 7.19^{c} \\
(425.15 \% \uparrow)\end{array}$ & $\begin{array}{l}5.70 \pm 4.17^{\mathrm{d}} \\
(54.89 \% \uparrow)\end{array}$ & $\begin{array}{l}5.64 \pm 2.73^{\mathrm{e}} \\
(53.26 \% \uparrow)\end{array}$ \\
\hline $\begin{array}{l}\text { Lung } \\
\text { (cytosol) }\end{array}$ & $8.42 \pm 4.58$ & $\begin{array}{c}9.24 \pm 5.92^{\mathrm{a}} \\
(9.74 \% \uparrow)\end{array}$ & $\begin{array}{l}6.84 \pm 2.4^{\mathrm{b}} \\
(1.58 \% \downarrow)\end{array}$ & $\begin{array}{c}8.28 \pm 6.19^{c} \\
(1.66 \% \downarrow)\end{array}$ & $\begin{array}{c}11.30 \pm 6.63^{\mathrm{d}} \\
(34.2 \% \uparrow)\end{array}$ & $\begin{array}{c}8.82 \pm 4.41^{\mathrm{e}} \\
(4.75 \% \uparrow)\end{array}$ \\
\hline $\begin{array}{l}\text { Forestomach } \\
\text { (cytosol) }\end{array}$ & $32.83 \pm 27.16$ & $\begin{array}{c}68.19 \pm 61.42^{\mathrm{a}} \\
(107.7 \% \uparrow)\end{array}$ & $\begin{array}{c}37.39 \pm 9.99^{\mathrm{b}} \\
(13.91 \% \uparrow)\end{array}$ & $\begin{array}{c}38.51 \pm 14.01^{\mathrm{c}} \\
(17.32 \% \uparrow)\end{array}$ & $\begin{array}{c}37.55 \pm 34.09^{\mathrm{d}} \\
(14.39 \% \uparrow)\end{array}$ & $\begin{array}{c}36.93 \pm 24.21^{\mathrm{e}} \\
(12.50 \% \uparrow)\end{array}$ \\
\hline $\begin{array}{l}\text { Heart } \\
\text { (cytosol) }\end{array}$ & $9.97 \pm 4.09$ & $\begin{array}{l}20.95 \pm 7.31^{\mathrm{a}} \\
(110.13 \% \uparrow)\end{array}$ & $\begin{array}{c}6.28 \pm 2.24^{\mathrm{b}} \\
(37.0 \% \downarrow)\end{array}$ & $\begin{array}{l}13.49 \pm 3.55^{\mathrm{c}} \\
(35.30 \% \uparrow)\end{array}$ & $\begin{array}{c}9.24 \pm 2.49^{\mathrm{d}} \\
(7.32 \% \downarrow)\end{array}$ & $\begin{array}{l}11.59 \pm 4.71^{\mathrm{e}} \\
(16.25 \% \uparrow)\end{array}$ \\
\hline $\begin{array}{l}\text { Brain } \\
\text { (cytosol) }\end{array}$ & $6.69 \pm 3.29$ & $\begin{array}{c}13.24 \pm 4.57^{\mathrm{a}} \\
(97.91 \% \uparrow)\end{array}$ & $\begin{array}{l}5.45 \pm 1.91^{\mathrm{b}} \\
(18.54 \% \downarrow)\end{array}$ & $\begin{array}{l}9.05 \pm 4.31^{\mathrm{c}} \\
(35.28 \% \uparrow)\end{array}$ & $\begin{array}{c}11.18 \pm 6.38^{\mathrm{d}} \\
(67.12 \% \uparrow)\end{array}$ & $\begin{array}{l}8.91 \pm 2.48^{\mathrm{e}} \\
(33.18 \% \uparrow)\end{array}$ \\
\hline
\end{tabular}

*Data were expressed as mean \pm SEM of triplicate assays and significant difference from control values. Significant differences between dose groups and control were assayed by the use of ANOVA, $(p<0.05)$.

activate chemical carcinogens. The changes in LP, LDH, antioxidative parameters, phase I and II enzymes can accelerate detoxification reactions. The increase in the cyt. $\underline{b}_{5}$ system is the result of an adequate detoxification of the activity of the metabolites by an increase in GST, DTD, GP, GR, CAT and SOD activities (Guan, He, 2015). Antioxidant enzymes can also be effective in the detoxification of toxic free radicals produced during normal cell metabolism as well as abnormal. Superoxide free radicals having the capacity to affect different macromolecules can be sufficiently detoxified by SOD and CAT enzymes.

\section{CONCLUSION}

ROS from the metabolic pathways cause the degradation of living organisms and damage to macromolecules. Peroxidation of lipids, protein inactivation and DNA mutation are the obvious consequences of free radicals. Since the reactions are rapid and complex chain reactions take place, only the indications are followed. Cellular defences against ROS are important detoxification of xenobiotic chemicals, polymerization of cell wall components and biosynthesis of complex organic molecules.

Thus, there are free and complex systems that eliminate active oxygen in plant cells. Some compounds, such as carotenoids, accelerate the flow of energy in photosystems and prevent the formation of oxygen. Some lipid soluble compounds inhibit the formation of lipid peroxidation chain reactions on the cell membrane. Antioxidant compounds such as ascorbate and glutathione eliminate active oxygen by directly detoxifying it. Enzymes that catalyze the synthesis, degradation and effective mechanism of these antioxidants are important for life.

The impact of EULA and EUFA extracts on mouse hepatic and extrahepatic XMEs, antioxidant enzymes, G6PD, 6PGD, LDH and sulfhydryl groups were evaluated by assessment of their activities. A significant increase in enzyme activities and structure suggested for the first time that EULA and EUFA might effectuate hepatic and extrahepatic enzymes. As a result, the different components of EULA and EUFA have effective antioxidant and detoxification activities and might be excellent regulatory abilities.

The effective changes indicated that EULA and EUFA extracts have significant changes and reliable marker in levels of biotransformation and antioxidative profiles.

\section{ACKNOWLEDGMENTS}

We would like to thank the Scientific and Technological Research Council of Turkey (TUBITAK) for financial support of this work (114Z683) and also the Samsun Metropolitan Municipality for providing of the EU samples. 


\section{CONFLICT OF INTEREST}

All authors declare no conflict of interest.

\section{REFERENCES}

Aebi, H. Catalase in vitro. Meth Enzymol. 1984;105:121-126.

Afrin S, Giampieri F, Gasparrini M, Forbes-Hernandez TY, Varela-López A, Quiles JL, Mezzetti B, Battino M. Chemopreventive and therapeutic effects of edible berries: A focus on colon cancer prevention and treatment. Molecules. 2016;21(169):1-40.

Beutler E. Glutathione in red blood cell metabolism. In: Beutler E, editor. A manual of biochemical methods. 2th ed. New York: Grune and Stratton; 1975. p 112-114.

Blot WJ, Li JY, Taylor PR, Guo W, Dawsey S, Wang GQ, Yang CS, Zheng SF, Gail M, Li GY, Yu Y, Liu BQ, Tangrea J, Sun YH, Liu F, Fraumeni JF, Zhang YH, Li B. Nutrition intervention trials in Linxian, China: supplementation with specific vitamin/mineral combinations, cancer incidence, and disease-specific mortality in the general population. J Natl Cancer I. 1993;85(18):1483-1491.

Borges LP, Brandão R, Godoi B, Nogueira CW, Zeni G. Oral administration of diphenyl diselenide protects against cadmium-induced liver damage in rats. Chem-Biol Interact. 2008;171(1):15-25.

Brisswalter J, Louis J. Vitamin supplementation benefits in master athletes. Sports Med. 2014;44(3):311-318.

Deepalakshmi K, Mirunalini S. Modulatory effect of Ganoderma lucidum on expression of xenobiotic enzymes, oxidantantioxidant and hormonal status in 7, 12-dimethylbenz (a) anthracene-induced mammary carcinoma in rats. Pharmacogn Mag. 2013; 9(34):167-175.

Dorman HD, Koşar M, Kahlos K, Holm Y, Hiltunen R. Antioxidant properties and composition of aqueous extracts from Mentha species, hybrids, varieties, and cultivars. J Agr Food Chem. 2003;51(16):4563-4569.

Emerole G, Thabrew MI. Changes in some rat hepatic microsomal components induced by prolonged administration of chloroquine. Biochem Pharmacol. 1983;32(20):3005-3009.

Flohe L, Otting F. Superoxide dismutase assays. Meth Enzymol. 1984;105:93-104.
Fordham IM, Clevidence BA, Wiley ER, Zimmerman RH. Fruit of autumn olive: a rich source of lycopene. HortScience. 2001;36(6):1136-1137.

George VC, Dellaire G, Rupasinghe HV. Plant flavonoids in cancer chemoprevention: role in genome stability, J Nutr Biochem. 2017;45:1-14.

Glasauer A, Chandel NS. Targeting antioxidants for cancer therapy. Biochem Pharmacol. 2014;92(1):90-101.

Guan YS, He Q. Plants consumption and liver health. EvidBased Compl Alt. 2015;2015:ID824185.

Guarisco J, Hall JO, Coulombe R. Butylated hydroxytoluene chemoprevention of aflatoxicosis-effects on aflatoxin B 1 bioavailability, hepatic DNA adduct formation, and biliary excretion. Food Chem Toxicol. 2008;46(12):3727-3731.

Gulcin I. Antioxidant activity of food constituents: an overview. Arch Toxicol. 2012;86(3):345-391.

Guner A, Aslan S, Ekim T, Vural M, Babaç M. Türkiye bitkileri listesi (damarlı bitkiler). Istanbul: Nezahat Gökyiğit, Botanik Bahçesi; 2012. p. 47-83.

Ismail T, Calcabrini C, Diaz AR, Fimognari C, Turrini E, Catanzaro E, Akhtar S, Sestili P. Ellagitannins in cancer chemoprevention and therapy. Toxins. 2016;8(151):1-22.

Ito H, Miki K, Yoshida T. Elaeagnatins AG, C-Glucosidic Ellagitannins from Elaeagnus umbellata. Chem Pharm Bull. 1999;47(4):536-542.

Kaur H, Chauhan S, Sandhir R. Protective effect of lycopene on oxidative stress and cognitive decline in rotenone induced model of Parkinson's disease. Neurochem Res. 2011;36(8):1435-1443.

Kiruthiga P, Karthikeyan K, Archunan G, Pandian SK, Devi KP. Silymarin prevents benzo (a) pyrene-induced toxicity in Wistar rats by modulating xenobiotic-metabolizing enzymes. Toxicol Ind Health. 2015;31(6):523-541.

Klotz AV, Stegeman JJ, Walsh C. An alternative 7-ethoxyresorufin O-deethylase activity assay: a continuous visible spectrophotometric method for measurement of cytochrome P-450 monooxygenase activity. Anal Biochem. 1984;140(1):138-145.

Kuhad A, Sethi R, Chopra K. Lycopene attenuates diabetesassociated cognitive decline in rats. Life Sci. 2008;83(3):128-134. 
Lodhi P, Tandan N, Singh N, Kumar D, Kumar M. Camellia sinensis (L.) Kuntze extract ameliorates chronic ethanolinduced hepatotoxicity in albino rats. Evid-Based Compl Alt. 2014;2014:ID787153.

Lowry OH, Rosebrough NJ, Farr AL, Randall RJ. Protein measurement with the Folin phenol reagent. J Biol Chem. $1951 ; 193(1): 265-275$.

Masters B, Williams C, Estabrook HKR, Pullman M. Methods in enzymology. New York: Academic Press; 1967. v. 10, p. 565-573.

Narayan C, Kumar A. Identification and characterization of phenolic compounds in hydro methanolic extract of Achyranthes aspera (HMEA) by UPLC and MALDI-TOF-MS and in vivo antioxidant activity. Orient Pharm Exp Med. 2013;13(1):51-59.

National Toxicology Program. Program NT. NTP technical report on the toxicology and carcinogenesis studies of 2,3,7,8-tetrachlorodibenzo-p-dioxin (TCDD)(CAS No. 174601-6) in female Harlan Sprague-Dawley rats (Gavage Studies). Technical Report 521. United States: National Toxicology Program Technical Report Series; 2006. p. 4-232.

Neki N. Oxidative stress and aging. Bangladesh J Med Sci. 2015;14(3):221-227.

Omura T, Sato R. The carbon monoxide-binding pigment of liver microsomes I. Evidence for its hemoprotein nature. J Biol Chem. 1964a;239(7):2370-2378.

Omura T, Sato R. The carbon monoxide-binding pigment of liver microsomes II. Solubilization, purification, and properties. J Biol Chem. 1964b;239(7):2379-2385.

Ozen T, Korkmaz H. Modulatory effect of Urtica dioica L. (Urticaceae) leaf extract on biotransformation enzyme systems, antioxidant enzymes, lactate dehydrogenase and lipid peroxidation in mice. Phytomedicine. 2003;10(5):405-415.

Ozen T, Korkmaz H. The effects of Urtica dioica L. leaf extract on aniline 4-hydroxylase in mice. Acta Pol Pharm. 2008; 66(3):305-309.

Ozen T, Yenigun S, Altun M, Demirtas I. Phytochemical constituents, ChEs and urease inhibition, antiproliferative and antioxidant properties of Elaeagnus umbellata Thunb. Comb Chem High Throughput Screen. 2017;20(6):559-578.
Patel S. Plant genus elaeagnus: Underutilized lycopene and linoleic acid reserve with permaculture potential. Fruits. 2015;70(4):191-199.

Prochaska HJ. Purification and crystallization of rat liver NAD (P) $\mathrm{H}$ :(quinone-acceptor) oxidoreductase by cibacron blue affinity chromatography: identification of a new and potent inhibitor. Arch Biochem Biophys. 1988;267(2):529-538.

Ray G, Batra S, Shukla NK, Deo S, Raina V, Ashok S, Husain SA. Lipid peroxidation, free radical production and antioxidant status in breast cancer. Breast Cancer Res Tr. 2000;59(2):163170 .

Rudack D, Davie B, Holten D. Regulation of rat liver glucose 6-phosphate dehydrogenase levels by adenosine 3', 5'-monophosphate. J Biol Chem. 1971;246(24):7823-7824.

Rudack D, Gozukara EM, Chisholm EM, Holten D. The effect of dietary carbohydrate and fat on the synthesis of rat liver 6-phosphogluconate dehydrogenase. BBA-Gen Subj. 1971;252(2):305-313.

Sharma V. Anti-carcinogenic potential of Euphorbia neriifolia leaves and isolated flavonoid against N-Nitrosodiethylamineinduced renal carcinogenesis in mice. Indian J Biochem Bio. 2013;50(6):521-528.

Schlenk D, Buhler D. Role of flavin-containing monooxygenase in the in vitro biotransformation of aldicarb in rainbow trout (Oncorhynchus mykiss). Xenobiotica. 1991;21(12):1583-1589.

Sedlak J, Lindsay RH. Estimation of total, protein-bound, and nonprotein sulfhydryl groups in tissue with Ellman's reagent. Anal Biochem. 1968;25:192-205.

Simons PC, Vander Jagt DL. Purification of glutathione S-transferases from human liver by glutathione-affinity chromatography. Anal Biochem. 1977;82(2):334-341.

Varshney R, Kale R. Effects of calmodulin antagonists on radiation-induced lipid peroxidation in microsomes. Int J Radiat Biol. 1990;58(5):733-743.

Wrafter PF, Connelly TM, Khan J, Devane L, Kelly J, Joyce WP. The 100 most influential manuscripts in colorectal cancer: a bibliometric analysis. Surgeon. 2016;14(6):327-336.

Received for publication on $04^{\text {th }}$ March 2017 Accepted for publication on $17^{\text {th }}$ May 2017 